\title{
Capital Flight to Germany: Two Alternative Measures
}

\section{Yin-Wong Cheung, Sven Steinkamp, and Frank Westermann}

Working Paper No. 115

August 2019

INSTITUTE OF EMPIRICAL ECONOMIC RESEARCH

Osnabrück University

Rolandstr. 8

49069 Osnabrück

Germany 


\title{
Capital Flight to Germany: Two Alternative Measures
}

\author{
Yin-Wong Cheung, Sven Steinkamp, Frank Westermann
}

This version: August 2019

\begin{abstract}
We use two measures to study two capital flight channels for Germany. One measure is based on the concept of trade misinvoicing and one on net claims and liabilities in the Eurosystem of central banks. For both measures, we propose refinements to enhance the assessment of capital flight. We find that capital flight towards Germany via these two channels has been quite sizable in the recent decade and can tally to about 2\% of GDP annually. Regarding their determinants, we show that the two capital flight measures are driven by both common and measure-specific factors. Traditional determinants such as covered interest differentials only play a limited role, while crisis-specific factors such as economic policy uncertainty, the ECB collateral policy, as well as currency misalignment are driving factors of the investors' apparent flight-to-safety behavior.
\end{abstract}

JEL Classifications: F3; F32; G15.

Keywords: Illicit Capital Flight; Trade Misinvoicing; TARGET2 Balance; Flight-to-safety; Economic Policy Uncertainty.

Acknowledgments: We thank Charles Engel, Maurizio Habib, Michael Hutchison, Filippo Natoli, Pavlos Petroulas, Kishen Rajan, Matthew Yiu, and the participants of the Conference on Global Safe Assets, International Reserves, and Capital Flow, 2019 for their comments and suggestions. Of course, we are responsible for any remaining deficiencies or errors. Cheung gratefully acknowledges the Hung Hing Ying and Leung Hau Ling Charitable Foundation (孔 慶焱及梁巧玲慈善基金) for its support through the Hung Hing Ying Chair Professorship of International Economics (孔慶炎講座教授(國際經濟)). Westermann acknowledges the support from the Deutsche Bundesbank's Regional Office in Bremen, Lower Saxony and Saxony-Anhalt.

Correspondence Addresses:

Yin-Wong Cheung: Hung Hing Ying Chair Professor of International Economics, City University of Hong Kong, Kowloon Tong, Hong Kong, E-mail: yicheung@cityu.edu.hk.

Sven Steinkamp: Institute of Empirical Economic Research, Osnabrück University, D-49069 Osnabrück, Germany, E-mail: sven.steinkamp@uni-osnabrueck.de.

Frank Westermann: Institute of Empirical Economic Research, Osnabrück University, D49069 Osnabrück, Germany; E-mail: frank.westermann@uni-osnabrueck.de. 


\section{Introduction}

Germany’s ballooning current account surplus experienced after the 2007/8 global financial crisis (Figure 1) has been widely discussed from a trade and fiscal policy perspective (Felbermayr et al. (2017), Kollmann et al. (2015), and references therein). As Germany does not accumulate official reserves via current account surpluses, a net outflow of goods and services implies a substantial corresponding private capital outflow. A parallel movement, however, which has received much less attention, appears to go in the opposite direction: There exists substantial capital flight towards Germany via either illicit capital flows, or flows which have been facilitated by reserve-like operations of national central banks in the Eurosystem.

An astute reader may question the relevance of studying illicit capital flight to Germany, which has in principle an open financial account. Germany’s major trading partners (e.g., China, Russia, India), however, do have capital controls in place. If there is capital flight out of these economies, there are corresponding inflows in other countries. As Germany is generally regarded as a safe haven, it can be a destination of some of these illicit flows (He et al., 2019).

The anecdotal evidence on illicit economic activities offers some hints on the potential economic and quantitative importance of illicit capital flight to Germany. Medina and Schneider (2018) for instance estimate the size of Germany's shadow economy to be $12 \%$. The magnitude is only slightly below the $14 \%$ estimated for China, which is widely considered to be a country with considerable illicit capital inflows and outflows (Beja, 2008; Ferrantino et al., 2012; Kar and Freitas, 2012; Cheung and Qian, 2010; Cheung et al., 2016).

The recent police raids at Deutsche Bank attest the seriousness of illicit capital flows to Germany. The German business newspaper Handelsblatt coined Germany the "Gangsters Paradise" in an article entitled "How Germany became the stronghold for Money Laundry."1 The newspaper report is more than an isolated instance. The "Financial Action Task Force (FATF),” a joint initiative of the OECD and the IMF, has repeatedly criticized Germany for its lenient stance on controlling illicit capital inflows. ${ }^{2}$

Not all capital flight towards Germany has been illicit, however. Within the euro area, German assets are considered to be "safe assets," as the country stands out in terms of its

\footnotetext{
${ }^{1}$ See, for example, "Deutsche Bank Raided in Laundering Probe Going Into 2018," Bloomberg Business, November 29, 2018, and "Gangster's Paradise - wie Deutschland zur Hochburg für Geldwäscher wurde," Handelsblatt, 25 July 2018. The articles highlight the rising number of convictions, which may only be a small part of the actual cases. A particular focus is on the real estate sector, where two institutional aspects play a role: (i) not all transactions are documented by an official notary, and (ii) the burden of proof is on the authorities. The practice is in contrast to that of, for example, Italy that requires buyers and sellers to prove the source of the money is legal.

${ }^{2}$ See, for example, Financial Action Task Force (2010, 2014), as well as recent steps towards a regulatory tightening as reflected in the new laws on money laundering (§261, §89c StGB).
} 
relatively strong fundamentals. Private households in countries affected by the European sovereign debt crisis, for instance, may be concerned about domestic policies and move their deposits to Germany. ${ }^{3}$ Banks that have lent large amounts of money to the euro area periphery have repatriated their funds for safe alternative investments, and owners of governments bonds are seeking to reshuffle their portfolios to minimize the associated default risks. Importantly for our paper, all of these transactions are examples of capital movement without a corresponding trade transaction in goods or services.

These net capital movements are reflected in Germany's large creditor position in the TARGET2 clearing system and are partly a by-product of the European Central Bank's (ECB's) decentralized implementation of monetary policy and the corresponding asymmetric liquidity provision across national central banks (NCBs). With the introduction of the ECB's full allotment policy, the NCBs refinancing operations support a swap of eligible collateral items in crisis-prone countries into assets of safe-haven countries, like Germany (Garber, 1999, 2010; Sinn and Wollmershäuser, 2012; Cecchetti et al., 2012; Reinhart, 2016; Steiner et al., 2019).

Capital flight via TARGET2 is reminiscent of capital flight from Mexico to the US prior to the breakup of the fixed exchange rate regime in 1994, where a monetary expansion helped investors to convert Mexican government bonds into safe assets denominated in US dollars. The key difference is that rather than running down reserves, like the Bank of Mexico in 1994, the euro area NCBs are running up TARGET2 liabilities vis-à-vis the Eurosystem and Germany is accumulating corresponding claims. Practitioners have been using the TARGET2 position as a barometer of capital flight within the euro area, in particular when analyzing the recent capital outflows from Italy and Spain. ${ }^{4}$ At the time of writing, Germany’s TARGET2 position amounts to about 30\% of GDP and is on an order of magnitude comparable to China's hoarding of international reserves, which is about $28 \%$ of GDP.

For devising initiatives and policies to curb capital flight to Germany, it is important to understand the mechanisms and determinants of these capital movements. In this paper, we conduct the exercise from the recipient country perspective and aim to accomplish three goals. First, we consider two alternative capital flight channels and, for each channel, propose a

\footnotetext{
${ }^{3}$ This behaviour has been covered in press articles such as "Capital Flight Leaves Banks in Germany Awash in Deposits,” Bloomberg, 8 June 2012, and “Investors rush for the safety of German Bunds,” Financial Times, 23 May 2012.

${ }^{4}$ See, for instance, "Capital flight from Italy surges, pushing TARGET2 imbalances to danger level”, The Telegraph, 7 June 2018; “The euro zone crisis - capital flight.”, The Economist (Buttonwood’s notebook), 21 May 2012. Cecioni and Ferrero (2012) dissect changes in TARGET2 during the early crisis period and confirm its movement to be mostly related to capital flight. In contrast, Auer (2014) finds both, current account financing and capital flight, to play a role.
} 
modified proxy to enhance our accuracy in measuring the corresponding unobserved capital flight and, and hence its properties. Second, we analyze the institutional setting that gives rise to net capital inflows despite an open financial account and highlight the similarity of the euro crisis to well-known earlier balance of payments crises. Finally, we investigate the determinants of capital flight - taking both economic and policy factors into consideration. In addition to the canonical determinants that include covered interest differentials, macroeconomic factors, and monetary policies, we distinguish between factors pertaining to Europe and those to the rest of the world. We further consider several economic policy uncertainty measures to assess the flight-to-safety motivation.

Our proxy measures of the two capital flight channels are: (1) a trade-cost adjusted measure of trade misinvoicing (TMI), and (2) the change in net claims and liabilities arising from open positions in the Eurosystem's clearing system, TARGET2, adjusted for current account balances and official flows (T2). These measures capture capital flight activities that are triggered by different motivations and considerations. For instance, we anticipate that illicit flows via TMI go through the trade channel, and are likely to be associated with trade intensity and long-term economic conditions. Capital flight visible in TARGET2 imbalances, on the other hand, is legal, mostly involves financial transactions, and works through the financial channel. Net transactions under TARGET2 are reminiscent of swap-line operations among central banks, but regionally limited to the euro area. They might be facilitated by expansionary monetary policy as well as the ECB’s collateral policy (Drechsler et al., 2016).

Empirically, we find that canonical determinants including the covered interest differential of Germany vis-à-vis the United States that is statistically insignificant in a multivariate regression, have only little impact on either measure of capital flight. Among fundamental drivers, the TMI measure responds to currency misalignment, exchange rate uncertainty, and the import duties ratio. An overvalued or volatile exchange rate has a dampening effect on capital inflows, while high import duties appear to make it attractive to circumvent these fees through misinvoicing.

Our T2 measure responds significantly to currency misalignment with the expected sign, as well as to government debt and the interest rate spread of government bond yields, which is consistent with the flight-to-safety motivation discussed above. Furthermore, we find that collateral standards, both for the common collateral framework of the Eurosystem, as well as the introduction of country-specific collateral items have influenced intra-euro area capital flight. A loosening of collateral standards drives capital into Germany, while a tightening has the opposite effect. 
A particular focus of our paper is on economic policy uncertainty that surrounds events of the euro crisis. Standard variables, such as monetary aggregates, as well as the debt- or deficit-to-GDP ratios are likely to capture the monetary and fiscal policy stance only partly around crisis periods. To capture a more general sense of uncertainty, we make use of newlydeveloped measures of economic policy uncertainty resting on the methodology by Baker et al. (2016).

Our results show that European Union (EU) economic policy uncertainty has been an important determinant of intra-euro area capital flight, while it appears to have played no visible role for TMI. Among the euro area countries, economic uncertainty in Greece, in particular, is statistically significant in the T2 regression. When further decomposing the sources of economic policy uncertainty, we find that uncertainty about the banking sector policy and future currency policy are key factors. The use of an interaction dummy variable approach indicates that these factors become relevant after the debate of private sector involvement (PSI), which had first been discussed at a meeting of the heads of state at the Deauville summit on 19 October 2010.

We perform a range of robustness checks. First, we compare our baseline regression results to those based on alternative measures of TMI with different specifications of costs of insurance and freight. Our results indicate that not taking into account the time- and countryvariation of these transaction costs can hinder the ability to precisely infer the TMI determinants. Second, we assess whether our results are affected by poor quality data by truncating countries from the sample which score in the bottom $25 \%$ - or $50 \%$-percentile of the World Bank's statistical capacity index. Third, we compare different adjustments of the T2 measure. We find that, while our refinements yield a conservative estimate of capital flight, the dynamics over time are largely driven by the TARGET2 variable itself. Finally, we employ different estimation methods. These include dynamic specifications, seemingly unrelated regressions, IV regressions with lagged values as instruments and various structural break specifications. Overall, the reported findings on the two capital flight channels stay remarkably robust across these alternative estimation methods.

\section{Measures of Capital Flight}

As there is little agreement on the exact definition of capital flight and its measurement (Claessens and Naude, 1993; Kant, 1996; Kar and Cartwright-Smith, 2009; Schneider, 2003), we consider two conceptually different measures that capture different types and motives of capital flight. 


\subsection{Trade Misinvoicing (TMI)}

Our first measure is trade misinvoicing (TMI). In principle, each country’s exports (and imports) are reported twice: by the country itself and by its trading partners. It is well-known, however, that often sizable differences between these mirror statistics can be observed. These differences, beyond differing reporting practices, are frequently attributed to intentional misinvoicing of international goods (Bhagwati, 1981, 1964; Cardoso and Dornbusch, 1989). ${ }^{5}$ An economic agent can, for instance, either underinvoice its exports or overinvoice its imports to move capital out of the country. Consequently, we calculate trade misinvoicing as the sum of export underinvoicing (EUI) and import overinvoicing (IOI); that is, $T M I=E U I+I O I$. Export underinvoicing and import overinvoicing are defined as

$$
E U I=\sum_{i}^{p}\left[X W_{i, t}-X C_{i, t}^{*}\left(1+C I F_{i, j, t}\right)\right],
$$

and

$$
I O I=\Sigma_{i}^{q}\left[M C_{i, t}-M W_{i, t}^{*}\left(1+C I F_{i, j, t}\right)\right]
$$

where, at time t, $X W_{i, t}$ is country $i$ 's reported value of imports from Germany, $X C_{i, t}$ is Germany's reported value of exports to country $i, p$ is the number of countries importing from Germany, $M C_{i, t}$ is Germany's reported value of imports from country $i, M W_{i, t}$ is country $i$ 's reported value of exports to Germany, and $q$ is the number of countries exported to Germany. Either a positive EUI or IOI implies (illicit) capital flows out of Germany. Note that, while export values are reported free on board (FOB), import values are commonly reported including the costs of insurance, freight, ..., etc. (CIF). The variable $C I F_{i, j, t}$ accounts for this wedge and is thus crucial for a precise estimation of trade misinvoicing. The time and countryvariation of the CIF, however, has largely been ignored by the empirical literature on trade misinvoicing.

Exploiting a new dataset by the OECD (International Transport and Insurance Costs of Merchandise Trade - ITIC) we infer and back out the CIF estimate that accounts for differences between trading partners, product types and periods. ${ }^{6}$ For a given year $t$, the country-pair CIF is a weighted average of the product-specific CIF with weights given by trade-volume values of individual products,

$$
C I F_{i, j, t}=\sum_{g=1}^{m} \widehat{C I F}_{i, j, t, g} \frac{v_{t, i, g}}{\frac{1}{m} \sum_{g=1}^{m} v_{t, i, g}}
$$

\footnotetext{
${ }^{5}$ We do not take a stance on which country's agents mis-invoice.

${ }^{6} \mathrm{~A}$ small subset of countries reports their imports in both, CIF and FOB. This allows the OECD to estimate the missing values from a gravity-type equation model (Miao and Fortanier, 2017).
} 
where $\widehat{C I F}_{i, j, t, g}$ is the product- and country-pair-specific CIF estimate at time t from the OECD dataset, $i=[1, \ldots, p]$ and $\mathrm{j}=[1, \ldots, p]$ are the partner and trading-partner country indices, respectively. $v$ is the trade volume and $g=[1, \ldots, m]$ the index of different OECD HS-92 product categories.

Other papers analyzing trade misinvoicing either explicitly or implicitly assume $C I F_{i, j, t}=10 \%, \forall i, j, t .^{7}$ The assumption does not match the empirical reality in several ways. First, Germany’s freight costs are on average very likely to be considerably lower. ${ }^{8}$ Second, freights costs are likely to vary over time (Hummels, 2007; Jacks et al., 2008). Third, the actual value of CIF can depend on which is the exporting and which one the importing country (Wei et al. 2018). Fourth, CIF varies with the geographical distance between countries. Based on a standard gravity model, trade volumes and freight costs are inversely related to the distance between countries. Not taking this into account can systematically bias trade misinvoicing estimates.

The literature usually takes a capital outflow perspective and considers trade misinvoicing to be related to the evasion of taxes and tariffs, the circumvention of capital controls, flight from economic risks (e.g., expansionary fiscal or monetary policies) in the home country, search for political stability, yield-seeking and arbitrage motives, the avoidance of exchange rate volatility, and the speculation on exchange rate adjustment (Cheung et al., 2016; Buehn and Eichler, 2011; Kellenberg and Levinson, 2019; Patnaik et al., 2012; Worku et al., 2016).

\subsection{Adjusted TARGET2-Balances (T2)}

Our second measure captures private capital flight within the euro area via the TARGET2 clearing system. It is reminiscent of the capital flight typically analyzed in the literature on balance of payments crises. Sachs, Tornell and Velasco (1996), for instance, describe this mechanism for the well-known case of Mexico. In Mexico 1994/5, the central bank provided credit to the domestic economy by buying assets and lending to banks. This liquidity was used by investors to convert Peso-investments into US-dollar investments at the central bank guaranteed fixed exchange rate of about 3:1. This capital flight was essentially a flight from

\footnotetext{
${ }^{7}$ See, for example, Beja (2008), Buehn and Eichler (2011), Patnaik et al. (2012), Kar and Freitas (2012). The CIF $=10 \%$ assumption is usually justified by an older estimate of the IMF. The International Monetary Fund (2015), for instance, argues "the 10 percent c.i.f./f.o.b. factor represents a simplified estimate of these costs, which vary widely across countries and transactions".

${ }^{8}$ OECD (2018), for example, cites official national sources on the German cif-fob margin to have been $2.3 \%$ in 2014 over all products and partner countries.
} 
risky assets (Mexican governments bonds) into safe assets (US Treasury bills). The expansionary policy stance of the central bank of Mexico facilitated this process.

Similarly in Europe, investors have been taking advantage of the expansionary policy stance of the ECB. In the Eurosystem, investors can pledge, for instance, Italian government bonds as collateral when borrowing from the Banca d'Italia-and use the central bank money to buy safe assets in Germany. The net capital outflows from Italy to Germany are then recorded as a TARGET2-liability of Banca d'Italia and a TARGET2-claim of the Deutsche Bundesbank. Indeed, financial market observers have been using TARGET2 as one of the key indicators to monitor the intensity of intra-euro area capital flight. ${ }^{9}$

While changes in TARGET2-balances are often by themselves interpreted as a measure of capital flight within the euro area, some adjustments are necessary. The TARGET2 balances also reflect capital flows by official institutions (e.g. the German government's payments into the European Stability Mechanism), as well as outright transfers, like development assistance. Further, they reflect flows related to the current account imbalances: Suppose a private agent in Italy would use some of her savings to buy goods - instead of financial assets - in Germany, and the Bank of Italy compensates this capital outflow by a loan to her private Italian bank. In this case, the payment-stream would simply reflect the large net exports of Germany within the euro area. While the central bank system certainly facilitates the transaction, it would not be considered capital flight (Sinn and Wollmershäuser, 2012; Whelan, 2014).

We, thus, account for these activities, and adjust the negative change in Germany's TARGET2-claims to obtain our second measure of capital flight:

$$
T 2=-(\Delta T A R G E T 2)+C A^{E A}+C A P^{E A}+F A^{E A, G o v},
$$

where $C A^{E A}$ and $C A P^{E A}$ are Germany's current account and capital account balances vis-à-vis the other member countries of the European Monetary Union, respectively, and $F A^{E A, G o v}$ are intra-euro area financial transactions of the German government. These adjustments do not substantially alter the time-series characteristics of the data, as most of the variation is driven by the TARGET2 component (see Section 4.4.2 below). However, they are necessary to avoid overestimating the level of capital flight. ${ }^{10}$

\footnotetext{
${ }^{9}$ Floyd Norris, the chief financial correspondent of The New York Times, wrote: "The Institute of Empirical Economic Research at the University of Osnabrück in Germany compiles the numbers on a website [www.eurocrisismonitor.com]. Some economists are waiting nervously to see if the numbers spiralled upwards in May.” (“Amid Uncertainty on Euro, Europeans Hedge Their Bets”, New York Times, May 31, 2012).

${ }^{10}$ There is the possibility that our approach might lead to an overestimation of outflows (or underestimation of inflows) and some further restrictions apply to eq. (4). In the robustness section, we discuss this issue and show that it is not particularly relevant in our dataset.
} 
There is very little research on the economic determinants of intra-euro area capital flight. The literature instead focuses on the empirical disentanglement of accounting identities of the TARGET2 balance, which has first been derived by Sinn and Wollmershäuser (2012). ${ }^{11}$ Our measure is inspired by their decomposition of TARGET2 balances into current account and financial account components. We additionally subtract the official flows to obtain our T2 measure. $^{12}$

There are some papers exploring the economic factors underlying the build-up of TARGET2 balances. Cecchetti et al. (2012) consider redenomination risk to be an important driver. De Grauwe and Ji (2012), after controlling for fundamental variables of country risk (i.e. government debt, the real effective exchange rate, and real economic growth), interpret the correlation between TARGET2 and government bond spreads as evidence for speculative panic and flight-to-safety. Whelan (2014) further discusses the positive link between central bank refinancing operations and the build-up of TARGET2 balances. ${ }^{13}$ None of the papers, however, considers an adjusted TARGET2 measure that isolates the private capital flight component from the current account-financing and public financing component, as in our T2 measure.

An alternative measure of capital flight is the World Bank Residual (e.g., Collier et al., 2004; Le and Zak, 2006; Cheung et al., 2017). We do not employ this measure here because it does not account for a large item of the German balance of payments statistics: Other investment (OI). The OI series, in turn, consists of a number of subcomponents, where the largest one is "Other Investment - monetary authorities." This subcomponent is largely composed of TARGET2 balances, which is closely related to our T2 measure. While for other countries, the World Bank Residual may be appropriate, it would vastly underestimate the true degree of capital flight for Germany.

\section{Preliminary Analysis}

The pattern and size of each measure of capital flight is displayed in Figure 2. We find that, during our (maximum) sample period, 1995Q1 to 2018Q3, capital flight to Germany has been rising and is economically not negligible after the 2007/8 global financial crisis; according to TMI it averages to about $1.48 \%$ of GDP annually, whereas T2 was $0.56 \%$ on average. Given

\footnotetext{
${ }^{11}$ The dispute centered on the question to what extent TARGET2 balances reflect current account financing or capital flight. Indeed, it reflected both - but to a different extent over time and across countries (Sinn and Wollmershäuser, 2012; Auer, 2014; Cecioni and Ferrero, 2012).

${ }^{12}$ Some countries outside the euro area, such as Norway, also participate in the TARGET2 clearing system. However, they are generally not allowed to run any negative balances.

${ }^{13}$ Westermann (2014), for example, critically reviews this positive link.
} 
the size of the German economy, the capital flight has accumulated to almost 600 billion euros over the past decade, or 70\% of today's GDP. It is also interesting to consider the sum of the measures over time. After 2008, both measures add up to 2.04\% of GDP; but before 2008, the sum is quite close to zero $(\sim 0.05 \%)$. If the measures represent different facets or components of capital flight, their sum suggests that the sizable net capital flight to Germany is a rather recent phenomenon.

The two capital flight measures capture net capital movements towards Germany under the covers of trade and financial transactions; these flows are likely to be committed by different clienteles with non-identical motivations. Indeed, TMI and T2 have a correlation coefficient of 0.265 ; indicating that they are related but also have their own unique dynamic features.

In order to correctly specify the regressions in the subsequent analysis, we first test for stochastic trends in our capital flight measures. Table 1 reports unit root tests. At the $5 \%$ level of statistical significance, we can reject the hypothesis of a unit root for both variables, over different sample periods and using different test statistic. ${ }^{14}$ Consequently, we treat our variables as $I(0)$ in the following regression exercise.

\section{Regression Analysis}

\subsection{Baseline Specification}

As a starting point, we consider the following specifications for TMI and T2:

and

$$
Y_{t, T M I}=\alpha+\lambda^{\prime} C I D_{t}+\theta^{\prime} X_{t}+\delta^{\prime} M_{t}+\beta^{\prime} W_{t}+\varepsilon
$$

$$
Y_{t, T 2}=\alpha+\lambda^{\prime} C I D_{t}+\theta^{\prime} X_{t}+\delta^{\prime} M_{t}+\beta^{\prime} Z_{t}+\varepsilon_{t},
$$

where $Y_{t, T M I}$ and $Y_{t, T 2}$ are, respectively, the TMI and T2 capital flight measure normalized by GDP. The explanatory variable $C I D_{t}$ is the deviation from the covered interest parity between the euro and US-dollar. Arguably, CID is the most commonly used factor to explain capital flight (Cuddington, 1986; Diwan, 1989; Dornbusch, 1984). The use of the EUR-USD covered interest differential captures the decision by a third country to move the capital to the US or Germany. The interest differential between Germany and other EU economies is considered later in (5b). Note that previous studies are mostly on capital flight of developing economies. ${ }^{15}$

\footnotetext{
${ }^{14}$ Cross-checking the result with the KPSS stationarity test confirms the I(0) finding - the two measures do not reject the null hypothesis of stationarity.

${ }^{15}$ Alesina and Tabellini, 1989; Bhagwati et al., 1974; Boyce and Ndikumana, 2001; Cerra et al., 2008; Collier et al., 2001; Cuddington, 1987; Epstein, 2005; Fedderke and Liu, 2002; Lensink et al., 1998, 2000; Le and Zak, 2006; Mikkelsen, 1991, and others. An exception is Javorcik and Narciso (2008) who focuses on tariff evasion via trade misinvoicing between Germany and its trade partners.
} 
Germany - a developed economy imposing limited capital controls - typically displays quite small covered interest differentials (Figure 3), and the CID effect can be small especially taking transaction costs into consideration. Nevertheless, given its prevalence in literature, we include this variable in our analysis. It is defined such that positive values indicate arbitrage opportunities by investing in Germany; we therefore expect it to have a negative (or zero) coefficient.

The vector $X_{t}$ includes the economic determinants that are deemed common to both TMI and T2 and capture investors' motives to avoid country risk (government debt, fiscal balance, real GDP growth), currency debasement (inflation differential, currency misalignment), volatile investments (stock price volatility), and to minimize taxation (tax ratio). We expect Germany to experience more inflows/less outflows when debts, deficits, volatility and taxes are low, the exchange rate is undervalued (positive coefficient) and economic growth is high (negative coefficient).

The vector $M_{t}$ includes M1 and M3 money growth rates that are considered in recent studies on capital flight. The relative monetary growth is indicative of the relative policy stance of Germany and the US and affects the capital flow pattern. Recent studies consider the money stock can be a measure of the intensity of the 'internal drain' and a proxy for potential capital flight (e.g. De Beaufort Wijnholds and Kapteyn, 2001; Cheung et al., 2016; Obstfeld et al., 2009). ${ }^{16}$

To capture the different natures of the two capital flight measures, we further include in (5a) $W_{t}$ that captures economic determinants that are specific for TMI, and in (5b) $Z_{t}$ that captures determinants specific to T2. Specifically, $W_{t}$ includes exchange rate volatility, the import duty ratio, the size of the shadow economy, and de facto trade openness. ${ }^{17}$ Capital inflows via TMI are hypothesized to respond negatively to a high degree of exchange rate uncertainty as measured by its realized volatility (positive coefficients). To circumvent tariffs and import VAT, firms have an incentive to underreport the true value of imports. This suggests a positive relationship between our import duty variable and capital outflows (negative coefficient). The signs of the coefficients on the shadow economy and trade openness do not come with a strong prior. On the one hand, shadow economy activities may generate black money cash which increases the demand for cross-border money laundering. On the other hand,

\footnotetext{
${ }^{16}$ The monetary aggregate may be indirectly related to QE policies of the FED and the ECB. There is however no direct relationship as M0 is only a small component of M2 and M3.

17 The choice of TMI-specific variables is motivated by, among others, Cheung et al., 2016; Buehn and Eichler, 2011; Kellenberg and Levinson, 2019; Patnaik et al., 2012; Worku et al., 2016.
} 
an active shadow economy may open up consumption opportunities for illicit inflows. De facto trade openness (proxied by the trade volume normalized by GDP) may also have opposing effects on TMI. While a higher trade volume (for given import duties) may be a proxy for the reduction of non-tariff trade barriers, thus lowering the incentives to underinvoice imports, a higher transaction volume may also open up more possibilities to misinvoice.

$Z_{t}$ includes changes in the interest spread of European countries affected by the euro crisis against Germany, Google searches for “euro breakup” as a proxy of redenomination risk, and variables capturing increased flexibility in the Eurosystem's collateral standards. We expect all of these variables to enter the regression with a negative coefficient. The interest rate spread aims to test the "financial panic" hypothesis and is expected to be positively correlated with capital inflows (De Grauwe and Ji, 2012; De Grauwe et al., 2017). In contrast to global capital flows via trade misinvoicing, capital flows within the euro area are unlikely to be influenced by misalignment or volatility of the common currency. T2 may, however, be affected by a noticeable increase in the perceived breakup-probability, and subsequent redenomination, in the height of the euro crisis (Cecchetti et al., 2012). ${ }^{18}$ Furthermore, lower collateral standards in refinancing operations facilitate the creation of central bank money; risky governments bonds can be pledged to the national central bank and the resulting liquidity can either be moved to Germany in the form of deposits or invested into other safe assets, such as bunds.

\subsection{Empirical Results}

\subsubsection{Determinants of Trade Misinvoicing (TMI)}

Table 2 reports the results of estimating variants of (5a). The CID variable is insignificant either as a standalone explanatory variable or in the presence of other variables. The finding is in contrast to the literature, which typically finds the CID to be a key determinant for capital flight. While the motive of earning arbitrage profits is deemed to be a prominent determinant of capital flight of developing economies, it does not appear to be a strong motivation to move capital to Germany. The insignificant result may not be surprising if we are talking about capital flight to Germany, which has an already quite open financial account and developed financial sector. We nevertheless keep the CID variable in the following analyses due to its prominence in the academic literature.

For the economic determinants included in the vector $X_{t}$, the real GDP growth, inflation differential, exchange rate misalignment, and government debt variables are statistically

\footnotetext{
${ }^{18}$ Also, ECB-president Mario Draghi remarked upon the "risk of convertibility" in a speech at the Global Investment Conference in London, 26 July 2012.
} 
significant with the expected signs (Column 2, Table 2). Specifically, capital flight via TMI to Germany increases with higher German real GDP growth, lower relative German inflation, an undervalued currency, and lower German government debt. The other fundamental variables used in the literature including the government balance relative to GDP, the tax ratio and stock market volatility are statistically insignificant.

Between the two money growth variables, only the relative M1 growth rate variable is significantly positive; that is, a relatively loose German monetary policy reduces flight to Germany (Column 3). The monetary effect, however, as indicated in the sequent results, is not robust to the presence of other determinants. ${ }^{19}$

Among the factors in $W_{t}$ that are deemed to be specifically relevant to TMI, only the openness variable is statistically insignificant (Column 4). The results indicate that a) exchange rate volatility capturing currency uncertainty deters capital flight, and b) the import duty ratio facilitates illicit inflows as higher import duties make it attractive for importers to incorrectly declare the values of imports. Both findings confirm the results reported in, say, for example, Patnaik et al. (2012), Cheung et al. (2016), Javorcik and Narciso (2008), Mishra et al. (2008), Ferrantino et al. (2012), and Fismann and Wei (2004).

Furthermore, we find that the estimated size of the shadow economy is inversely related to illicit inflows. When these potential determinants are included simultaneously (Column 5), most of the variables become insignificant; a result that is likely driven by either correlation of the variables or inclusion of irrelevant variables. Column (6) presents the results of sequentially dropping the "most" insignificant variable from the regression; that is, those with the lowest tstatistic. The resulting parsimonious specification shows that both monetary and shadow economy effects reported under Columns (3) and (4) are not robust in the presence of other economic determinants. The parsimonious specification explains over half (57\%) of the variations in TMI, the six significant determinants have their expected signs.

\subsubsection{Determinants of Adjusted TARGET2 Balances (T2)}

The results of estimating the baseline specification of T2 (5b) are presented in Table 3. Comparing the explanatory variables that are common to (5a) and (5b), the T2 capital flight measure is only significantly affected by a few. The CID variable displays a significantly negative effect as a standalone regressor or when it is paired up with monetary factors

\footnotetext{
${ }^{19}$ These results resemble findings of Cheung et al. (2016) for China.
} 
(Columns 1 and 3). However, the effect is not robust to the inclusion of other control variables. ${ }^{20}$

Of the four variables in $Z_{t}$, the vector that collects factors specific for $\mathrm{T} 2$, the interest rate spread of the European countries in crisis vis-à-vis Germany matters (EA Spread), ${ }^{21}$ as well as collateral standards in refinancing operations of the ECB. The two other variables are insignificant. It is worth noting that these two significant T2-specific factors explain $38 \%$ of data variability - a level of explanatory power that is much higher than those offered by CID, canonical economic and monetary variables.

The interest rate spread has a negative sign, which at first sight appears surprising. A lower interest rate in Germany vis-à-vis other European countries thus drives capital into Germany, rather than out of Germany. This is puzzling when applying the same arbitrage motivation as when interpreting the CID coefficient. Note, however, that while the CID variable used a very short-term money-market interest rate, the interest rate spread in Table 3 is computed as the difference in 10-year government bond yields. Indeed, the spread is usually viewed as a barometer of perceived country-risk differences within the euro area. ${ }^{22}$ After a phase of decoupling between fundamentals and interest rates, investors started to again notice that Germany and other European countries, with weaker fundamentals, do not share the same risk category. The negative coefficient is thus in line with the partial correlation between TARGET2 and the interest rate spread found by De Grauwe and Ji (2012); higher default risk in other euro area countries drives capital into Germany, rather than in the other direction. ${ }^{23}$ Note that, due to the countervailing effects, the size of the coefficient represents a lower-bound estimate.

The findings on collateral standards are in line with the institutional background characteristics of ECB monetary operations. NCBs in the euro area lend to banks against eligible collateral. Part of this collateral is determined by the ECB council, and (a smaller) part has been determined by the NCBs (idiosyncratic component). Some NCBs, for instance,

\footnotetext{
${ }^{20}$ When including the CID's subcomponents (i.e. the short-term interest rate differential and the forward premium), they also turn out to be statistically insignificant in the multivariate specifications of both, the TMI and T2 measure. The results are not reported but are available upon request.

${ }^{21}$ Ireland, Italy, Portugal, and Spain. Greece is excluded due to low liquidity of its debt securities as well as any convoluting effects from the Greek debt restructuring of 2012. Results are robust to the inclusion of Greece and are available upon request.

${ }^{22}$ The spread on covered default swaps (CDS) would be an alternative measure to capture country-risk differences. However, due to data paucity, the use of CDS implies a much shorter sample period for the exercise. Further, for the available data on 10-year spreads on CDS and government bond yields are highly correlated with a correlation coefficient estimate of 0.954 .

${ }^{23}$ The apparently counterintuitive sign has first been found and discussed in Cuddington (1987) for a set of emerging market economies.
} 
adopted special collateral items after the peak of the crisis in 2011, including ELA - the ECB's emergency liquidity assistance facility. Our regression findings imply that whenever these collateral standards were loosened, part of the liquidity created has been used for capital flight; when they were tightened (for instance in mid-2011), the intra-euro area capital flight is discouraged (Sinn and Wollmershäuser 2012; Whelan, 2014; Westermann, 2014).

In deriving the parsimonious specification from all these potential factors, we found that, in addition to three T2-specific factors, two economic variables; namely the currency misalignment and government debt variables are statistically significant. While these two economic variables are insignificant under Column (2), they are significant with the expected signs in the presence of, say, T2-specific factors; indicating a certain degree of complementarity between these variables. Overall, the T2 measure of German capital flight is explained by both, fundamental, as well as measure-specific factors. Taken together, these variables account for $43 \%$ of the $\mathrm{T} 2$ variability.

\subsection{The Role of Economic Policy Uncertainty}

While fundamental data on policy variables, in particular monetary and fiscal policy, are included in our specification, they may not represent all aspects of global or regional uncertainty that drive flight-to-safety (Le and Zak, 2006). For instance, inflation has been quite stable in the past, but central banks around the world have taken a policy stance that makes the path of future inflation very uncertain. The same applies to fiscal policies, where the effects of the debt-brake for instance - although part of the constitution in all euro area countries - were quite unpredictable. In this subsection, we consider alternative measures of economic policy uncertainty (EPU) in our analysis:

and

$$
Y_{t, T M I}=\alpha+\lambda^{\prime} C I D_{t}+\theta^{\prime} X_{t}+\delta^{\prime} M_{t}+\beta^{\prime} W_{t}+\gamma^{\prime} U_{t}+\varepsilon_{t},
$$

$$
Y_{t, T 2}=\alpha+\lambda^{\prime} C I D_{t}+\theta^{\prime} X_{t}+\delta^{\prime} M_{t}+\beta^{\prime} Z_{t}+\gamma^{\prime} U_{t}+\varepsilon_{t},
$$

where the vector $U_{t}$ captures the EPU related variables and the other covariate vectors are limited to only include the subset of statistically significant variables derived in the previous section. These EPU related variables are meant to represent uncertainty not captured by variables such as stock market volatility, interest rate spread, and exchange rate volatility considered in the previous subsection.

The measures follow a newly-developed methodology of Baker, Bloom and Davis (2016) and rely on the relative frequency count of words of uncertainty and economic policy in either 
newspapers or expert reports of the Economist Intelligence Unit (Ahir, Bloom, and Furceri, 2018). The data appendix provides detailed descriptions of these EPU indices.

As the TMI measure does not respond to any of these policy uncertainty indices, we for brevity do not present here these TMI results, which are available upon request.

For the T2 variable, we start with the Germany EPU index, the EU EPU index, and a global EPU index (Table 4). While all of them are statistically significant, when included individually, only the EU EPU index remains significant when all are included jointly and survived a stepwise regression. $\mathrm{Cl}$. (1) and $\mathrm{Cl}$. (2) show that both, the news-based and the expert-based index is statistically significant, i.e. higher economic policy uncertainty in the EU facilitates capital flight towards Germany - the safe haven. This result resembles findings by Hermes and Lensink (2001), who also analyze the link between policy uncertainty and capital flight; albeit with a focus on least developed countries and using different measures of capital flight and policy uncertainty.

As the three variables are highly correlated, indicating the presence of a common sentiment component, we extract their $1^{\text {st }}$ principal component and indeed find it to be highly significant. Adding it to the baseline regression derived in Section 4.2. yields a negative and statistically significant partial correlation with our T2 measure as well. This result is consistent with the existence of a general climate of economic sentiment, which either reflects global trends or is not regionally confined due to strong spill-overs from high-uncertainty countries; with the European countries in crisis being likely sources.

To follow up on the question of the sources of uncertainty, we look into some of the subcomponents of the EU EPU variable. Among the potential suspects, we find that policy uncertainty in Greece, in particular, has been driving capital (euro-area wide) into Germany. The other countries also have the expected negative signs but lower coefficients. Also, they are either insignificant (Ireland, Italy, and Portugal) or are only marginally significant at the $10 \%$ level (Spain).

Overall, economic policy uncertainty - not picked up by the variables considered in the previous subsection - appears to be a relevant additional factor; the adjusted $\mathrm{R}^{2}$ estimate of the regression increases from 0.43 to up to 0.48 .

Other variables, aimed to capture different aspects of uncertainty, such as a geopolitical risk (measured either by violent conflicts or the geopolitical risk index by Caldara and Iacoviello, 2018), dummy variables for the Greek private sector involvement (PSI), as well as the Deauville meeting, where the option of a PSI was first discussed, the introduction of EUwide bail-in clauses for bank debt coming with the Single Resolution Mechanism (Schäfer et 
al., 2017), stock market volatility in the US or Europe (captured by the VIX/VSTOXX) have turned out to be statistically insignificant and are not reported above (results are again available upon request).

In the appendix, we further decompose the effect of economic policy uncertainty on intraeuro area capital flight. First, as reported in Table B1, we break down the Greek economic policy uncertainty into its thematic components. We find, for a given level of overall EU policy uncertainty, that some subcomponents of Greek uncertainty are of additional importance. Especially, economic policy uncertainty regarding the banking sector and the currency enters the regression with a negative and statistically significant coefficient. Tax-, debt-, fiscal-, monetary- and pension-related economic uncertainty indices, turn out to be statistically insignificant (or only marginally significant). When going the opposite route and looking at a broader uncertainty index not related to specific policy discussions but rather all types of (perceived) economic uncertainty, this variable turns out to be statistically significant with a negative sign as well. In sum, the results indicate not only overall EU policy uncertainty fuels capital flight to Germany but also uncertainty surrounding the Greek crisis, in general, and banking and currency uncertainty, in particular.

Finally, in Table B2, we test for potential non-linearities over time. The Deauville meeting, where the possibility of PSI has first been discussed may have changed the way that economic uncertainty measures have influenced capital flight (Mody, 2013). As Table B2 shows, the interaction term of EPU $\times$ PSI is not statistically significant in most regressions. Nevertheless, the Wald-tests suggests that the sum of the coefficients on EPU and EPU $\times$ PSI is significant in all cases except Ireland and Portugal, while the EPU variable in the same regression by itself is not. This suggests that economic policy uncertainty is indeed a factor that has become relevant after the beginning of private sector involvement, which is analogous to a retrenchment of bailout expectations, which previously may have existed.

\subsection{Robustness}

\subsubsection{Measuring Trade Misinvoicing}

An advantage of our TMI measure is that it allows for variations across trading partners and over time. Columns (2) and (3) of Table 5 compare our baseline results, replicated in Column (1), with those from data derived from alternative assumptions regarding the CIF. The comparison shows that a precise estimation of the CIF is indeed crucial. While the TMI based on alternative CIP assumptions garner determinants, in general, with the same signs, our 
baseline TMI measure picks up more statistically significant variables than the other two measures.

Column (2) presents results of the TMI constructing with CIF estimates from the Centre d'Etudes Prospectives et d'Informations Internationales (CEPII). Both CEPII and OCED estimates follow comparable estimation approaches, but the CEPII dataset has a smaller crosscountry coverage (Gaulier and Zignago, 2019). While the signs of the coefficients remain the same for all variables, the statistical significance varies. Most notably, currency misalignment does not enter in a statistically significant way anymore. Also, the adjusted $\mathrm{R}^{2}$ estimate is considerably lower; it decreases from $57 \%$ to $42 \%$.

The previous literature on trade misinvoicing usually does not account for variations in costs of insurance and freight over time and across countries. ${ }^{24}$ Column (3) thus compares our baseline estimates to those from the TMI based on the common assumption of a constant CIF of $10 \%$. Remarkably, most of the variables become statistically insignificant in this case. Overlooking the variability of CIF estimates can limit the ability to explain capital flight variations. ${ }^{25}$

Another potential factor causing discrepancies in mirror trade statistics besides intentional misinvoicing is data quality and reliability of reporting countries. To address data quality issues, we re-constructed the TIM measure by dropping trading partners which have a low score of the Statistical Capacity Indicator compiled by the World Bank. Specifically, we drop those have a score a) in the lowest quartile, and b) below the median. The regression results based on these two restricted TMI measures are presented under Columns (4) and (5), and they are quite similar to the baseline results regarding the size of the coefficients as well as their statistical significance. Dropping the lowest quartile of countries decreases the standard errors of our estimates only slightly, while dropping all countries below the median marginally increases them. Overall, dropping trading partners that may not offer quality data does not affect our results of factors affecting capital flight.

We performed sensitivity analysis on our T2 measure by analysing different types of data adjustments, as well as a pure TARGET2 series. Table B3 of the appendix shows that the results are qualitatively similar. The finding confirms the assessment that the adjustments are primarily performed to derive a conservative level-estimate of capital flight while leaving the time-series characteristics largely unchanged.

\footnotetext{
${ }^{24}$ Cheung et al. (2016) - to the best of our knowledge - is the first capital flight study using CEPII data.

${ }^{25}$ In a passing, we note that the $\mathrm{R}^{2}$ increases to $70 \%$ in this specification. This, however, is likely to be caused by the TMI measure (based on constant-CIF) not being stationary.
} 
In principle, our proxy could also have the issue of an overestimation of outflows (as well as underestimation of inflows). As a further refinement, we omit the subtraction of negative current account values for positive TARGET2 values (and positive current account values for negative TARGET2 values, respectively). We also set capital flight to zero, when positive TARGET2 values are smaller than positive current account values (and when negative TARGET2 values are smaller than negative current account values). ${ }^{26}$ The correlation of the resulting series with our baseline proxy is 95.9\%. The last column in Table B3 shows that the results are again similar to our benchmark regression.

\subsubsection{Estimation Methods and Specification Issues}

As another robustness test, we consider different estimation methods and specifications in Tables 6 (TMI) and 7 (T2).

First, we adopt a Seemingly Unrelated Regression (SUR) estimation approach to allow for possible interactions between the TMI and T2 equations. The SUR results displayed under Column (2) of Tables 6 and 7 are mostly similar to the corresponding ones in Tables 2 and 3. There are only marginal changes on the estimation coefficients, although the adjusted $\mathrm{R}^{2}$ estimates suggest that SUR provides an overall better fit. However, it is noted that the SUR approach restricts the estimation to the common sample period, which results in losing 16 quarterly observations for TMI. The OLS regression residuals have a positive correlation - but it is rather small (0.183) and a Breusch-Pagan $\chi^{2}(1)$ test-statistic of 2.567 with a p-value of 0.109 does not reject the null hypothesis of independence. That is, the single equation estimation is relevant.

Second, we experiment with a dynamic specification. Despite the Durbin-Watson statistics - 2.07 for the TMI equation, and 2.66 for the T2 equation - do not indicate serious issues, we investigate if our results are sensitive to the inclusion of an $\mathrm{AR}(1)$-component. The lagged endogenous variable is neither statistically significant, nor does its inclusion change any results substantially (Columns (3) of Tables 6 and 7). ${ }^{27}$

In Tables 6 and 7, we also address the issue of endogeneity in a set of instrumental variables (IV) regressions. Specifically, the interest rate variables as well as the import duties maybe endogenous with respect to our dependent variables. The estimation results from instrumenting both variables with their respective lagged values are presented under Columns (6) and (7). The use of IV does not materially change the estimation results pertaining to the

\footnotetext{
${ }^{26}$ See data appendix for exact definition.

${ }^{27}$ The same is true when other methods to control for autocorrelation are used. A Prais-Winsten AR(1) regression results in a smaller (transformed) Durbin-Watson-statistic of 2.12, but does not change our results notably (available upon request).
} 
instrumented variables as well as the other variables in the regression. The IV specifications exhibit no signs of under-, weak-, or over-identification; except for Column (6) of Table 7 that seems to be only weakly identified. ${ }^{28}$

Finally, we do not find evidence for unaccounted structural breaks. Potential structural breaks attributed to the adoption of the euro and the onset of the European crisis are assessed, respectively, using a dummy variable of the accession to the European Monetary Union for TMI and a dummy variable of the euro crisis for T2. The results presented under Columns (8) of Tables 6 and 7 indicate no significant effect of these two structural break dummy variables. ${ }^{29}$

Table B4 of the appendix further examines the effect of the Eurosystem's quantitate easing (officially named Extended Assets Purchase Programme - APP). Observers have repeatedly referred to the direct effect of the asset purchases on recorded capital flows (Eisenschmidt et al., 2017). Columns 1 and 2 of Table B3 assess whether the adoption of APP indeed affects our T2 measure. While the coefficients have the expected negative signs, they are not statistically significant. We furthermore examine the interaction of the APP with the Eurosystem's collateral standards. With the adoption of the APP, refinancing operations become a less important source of bank funding; this may weaken the link between collateral standards and capital flight. While the signs of the coefficients are consistent with this reasoning, the effect of loosened collateral standards did not weaken in a statistically significant order of magnitude.

\subsubsection{Additional Robustness Tests}

As a last set of robustness tests, we consider the effect of bank creditors' bail-in expectations, the Global Financial Crisis of 2007/08, the European sovereign debt crisis (starting in 2010), and CDS spreads as opposed to government bond spreads. The results are reported in Appendix C.

First, we added three different potential bail-in variables to our benchmark regression (Table C1). None of them displays a statistically significant coefficient estimate. The three variables are constructed to capture effects of (i) the agreement of EU Finance ministers upon

\footnotetext{
${ }^{28}$ The spread may also be jointly determined (instead of being endogenous). We, therefore, computed the partial correlation in a stricter sense (i.e. regressing both variables on a common set of potentially jointly-determining variables and then looking at the correlation of the residuals of both equations). We find that T2 and the interest rate spread are still partially correlated even if the influence of all other variables is backed out of both variables. Results are available upon request.

${ }^{29}$ Note that the T2 sample is 1999q1-2018q2, while the TMI sample is 1995q1-2018q2. This makes a symmetric inclusion of a dummy variable difficult. We have opted for dummies that leave a substantial part of the sample period on both sides of the potential structural breakpoint.
} 
the Bank Recovery and Resolution Directive in June 2013, thereby preparing the bail-in rules for the Single Resolution Mechanism (SRM), (ii) the provisional agreement in March 2014 of the European Parliament and the Council on the proposed SRM, and, finally, (iii) its adoption by the European Parliament in April 2014.

Second, we analyze the potential difference between the crisis period and tranquil times. The results are reported in Tables C2 and C3 for the T2 measure and Tables C4 and C5 for the TMI measure. We used interaction dummy variables to capture the effects of the post-2008 global financial crisis and the post-2010 European sovereign debt crisis periods. With an exception of the currency misalignment variable which appears to be significant at the $10 \%$ level in the post-2008 period, these interaction terms are statistically insignificant.

Third, we consider CDS as an alternative proxy for default risk in our benchmark regression. When we replaced government bond spreads with CDS spreads in our benchmark specification, we obtain results (Table C6) that are qualitatively similar to those reported here; the finding is not surprising as the correlation of the CDS and bond spreads is 0.954 during the sample period.

\section{Conclusions and Policy Implications}

Using two modified measures, our analysis reveals that there exist (at least) two distinctly different channels via which capital flight towards Germany can be observed. ${ }^{30}$ Arguably, all empirical measures are noisy proxies of capital flight - illicit or not, and including ours. By incorporating both time-variation and trade partner variabilities, our refined TMI measure, however, shall allow for a more reliable assessment of trade misinvoicing activity. Our proposed T2 measure, which adjusts the TARGET2 balance for the payment streams associated with the net purchase of goods and services and official sector transactions, shall provide a more accurate, albeit conservative, assessment of intra-euro area capital flight, and be relevant for monitoring the ongoing fragmentation of the euro area's capital market and the flight-tosafety behavior of international investors.

Our empirical exercise shows that the two capital measures are affected by both economic determinants and policy/institutional factors. This information is important for policymakers: If they aim to curb capital flight, for instance, it is not sufficient to implement

\footnotetext{
${ }^{30}$ Of course, capital flight can take also place via other channels which can be captured by different measures including those constructed from, say, the World Bank Residual method, the Errors and Omissions approach, or the Hot Money method. In passing, we note that, to our surprise, our T2 measure and the official errors and omissions series have a correlation coefficient estimate of 0.537 . To shed additional light on Germany's capital flight, further research on these alternative measures is warranted.
} 
national regulatory reforms, as suggested by the FATF task force. It is also important to take macroeconomic developments into accounts that are ultimately driving the capital flight towards Germany. Also, if Germany - or the euro area as a whole - intend to limit intra-euro area capital flight, it is important to take into account of economic policy and political uncertainties, which can drive these capital flows, beyond pure macro indicators such as debtor deficit-to-GDP ratios. The ECB governing council, when designing its collateral policy, may take side-effects on capital flight into consideration.

Furthermore, our study investigates capital flight from the perspective of a recipient, or "safe-haven country", instead of the common perspective of an originating country. In this regard, our exercise can be relevant for other countries such as Switzerland, the Netherlands and Norway, which all have become the target of similar capital flight movements. While capital flows associated with an exchange of goods and services can be welfare-enhancing capital movements, pure capital flight constitutes a challenge for both the sending and the receiving countries.

Although our exercise offers evidence of (illicit) capital flight towards Germany even in the presence of minimal capital control policies, we do not explicitly analyze, say, the implications for financial stability, and the welfare implications for Germany, other euro area countries, or the global economy. While these issues are beyond the scope of the current exercise, they warrant further research efforts. 

measured either (i) by freight-cost-adjusted trade misinvoicing (TMI), or (ii) the adjusted change in TARGET2-claims (T2). See below for details.

The adjusted TARGET2 measure is defined as T2 = D(TARGET2) + CA_EA - CapA - FA_Gov, where D(TARGET2), CA_EA, CapA and FA_Gov are the following balance of payments items of Germany vis-à-vis today's euro area member countries (EA19, fixed composition): D(TARGET2) is the negative change in Germany's TARGET2-claims as a (excluding claims/liabilities from under-/over-issuance of banknotes), CA_EA is the current account balance, CapA, the capital account and FA_Gov are financial account transactions of the German government (e.g. payments to the European Stability Mechanism). T2 is expressed as a percentage of nominal GDP. Data sources: Bundesbank (Codes: BBFI1.M.N.DE.4F.S121.S1.LE.A.FA.O.F2_T2 .S._T.N.N; BBFB1.Q.N.DE.I8.S1.S1.T.B.CA._Z._Z._Z._T._X.N; BB FB1.Q.N.DE.I8.S1.S1.T.C.KA._Z._Z._Z._T._X.N; BBFB1.Q.N.DE.I8.S1.S1.T.D.KA._Z._Z._Z._T._X.N; BBFB1.Q.N.DE .I8.S13.S1.T.A.FA .O.F2.T._T. N.N).

T2, Restricted

As T2, but the following two restrictions apply to eq. (4): i) For $(\triangle T$ TRGET2 $>0$ and $C A<0)$ or $(\triangle T A R G E T 2<0$ and $C A<0)$, we set $\mathrm{CA}=0$, ii) For $(\mathrm{CA}>\Delta \mathrm{TARGET} 2>0)$ or $(0>\mathrm{CA}>\Delta \mathrm{TARGET} 2)$, we set $\mathrm{T} 2=0$.

$T M I$

Capital flight measured by the net trade misinvoing method given by the sum of export underinvoicing and import overinvoicing, i.e. $T M I=\sum_{i}^{p}\left[X W_{i, t}-X C_{i, t}^{*}(1+C I F)\right]+\sum_{i}^{q}\left[M C_{i, t}-M W_{i, t} *(1+C I F)\right]$, where $X W_{i, t}$ is economy $i$ 's reported value of imports from Germany, $X C_{i, t}$ is Germany‘s reported value of exports to country $i, M C_{i, t}$ is Germany's reported value of imports from country $i, M W_{i, t}$ is economy $i$ 's reported value of exports to Germany, $p$ is the number trading partners, and CIF is the c.i.f./f.o.b. CIF estimates are from the OECD (see separate appendix for details). TMI is expressed as a percentage of nominal GDP. Positive values indicate outward capital flight. Data sources: Directions of Trade Statistics (IMF), International Transport and Insurance Costs of Merchandise Trade (OECD) by Miao and Fortanier (2017).

APP Dummy A dummy variable, given by the indicator function $I(t>=2015 \mathrm{Q} 1\})$, capturing the adoption of the Eurosystem’s Extended Assets Purchase Programme (APP).

APP Monthly Purchases Bank Bail-in
Average volume of monthly assets purchases of the Eurosystem under the extended APP in billions of Euros.

Bank Bail-in variables (1), (2) and (3) are given by the indicator functions I(t >=2013Q2\}), I(t >=2014Q1\}), I(t >=2014Q2\}), respectively. These dates reflect the agreement of EU Finance ministers upon the Bank Recovery and Resolution Directive in June 2013, thereby preparing the bail-in rules for the Single Resolution Mechanism (SRM), the provisional agreement in March 2014 of the European Parliament and the Council on the proposed SRM, and, finally, its adoption by the European Parliament in April 2014.

Quarterly average of Germany's daily covered interest differentials. It is given by the nominal interest rate differential $(R D i f f)$ plus the forward premium $(F P)$, i.e. $C I D=R D i f f+F P=\left(r-r^{*}\right) /\left(1+r^{*}\right)+(F-S) / S$, where $r$ is the London interbank offer rate (DM-based until 1998; then EUR-based), $r *$ is the US\$ LIBOR, $F$ is the forward rate and $S$ is the spot exchange rate (DM/USD until 1998; then EUR/USD). $r, r^{*}$ and $F$ are annualized three-month rates in daily frequency. Data sources: Bundesbank (Codes: BBK01.ST0268; BBK01.ST0316); ICE Benchmark Administration Ltd. via Datastream (B5DEM3M; B5EUR3M; B5USD3M), Datastream (Codes: WG90DUS; TDEUR3M).

Difference of the simple average of covered default swap prices for a full restructuring of 10-year government bonds of Ireland, Italy, Portugal, and Spain vis-à-vis Germany. Data sources: Datastream. 
Collateral Standards

Collateral (Idiosyncratic)

Currency Misalignment

Current Account

D08

D10

EA Spread

Gov. Debt

Economic Policy Uncertainty (news)

Economic Policy Uncertainty

(expert)

Exr. Volatility

Forward Premium

Geopolitical Risk Index

Gov. Bal.

Inflation Diff.
Categorical variable taking the value +1 whenever the ECB governing council loosened collateral standards for refinancing operations, -1 when it was tightened, 0 otherwise. We ignore decision ECB/2013/6 as it was reversed before it came into force (ECB/2015/9). Data sources: Eberl and Weber (2014), updated by authors.

A dummy variable, given by the indicator function $I(t=\{2011 \mathrm{Q} 4\})$, capturing the ECB governing council's decision to allow country-specific collateral requirements.

Deviation from estimated equilibrium exchange rate (in \%). Positive values indicate overvaluation, negative undervaluation. Quarterly frequency interpolated from annual data using cubic splines. Data source: CEPII EQCHANGE (average index), see Couharde et al. 2018 for details.

Germany's current account balance from its balance of payments statistics as a percentage of nominal GDP (both in national currency). Seasonally adjusted using US Census' X-11 method. Data source: Bundesbank (Code: BBFB1.Q.N.DE.W1.S1.S1.T.B.CA._Z._Z._Z._T._X.N).

Dummy variable given by the indicator function $\mathrm{I}(\mathrm{t}>=2008 \mathrm{Q} 1\})$, capturing the period since the Global Financial Crisis,

Dummy variable, given by the indicator function $\mathrm{I}(\mathrm{t}>=2010 \mathrm{Q} 1\})$, capturing the period since the Euro Crisis,

Simple average of long-term (10y) government bond spreads of Ireland, Italy, Portugal, and Spain vis-à-vis Germany. Data sources: OECD (Finance).

Germany’s gross consolidated general government debt as percentage of nominal GDP (seasonally adjusted). Data before 2000Q1 have been interpolated from annual to quarterly frequency using cubic splines. Data source: Federal Statistical Office (Destatis), Eurostat (Code: gov_10q_ggdebt).

Global and US indexes of economic policy uncertainty based on normalized newspaper coverage frequencies. Source and description: Baker et al. (2016) and updates from their website.

Global and regional indexes of economic policy uncertainty based on the frequency counts of the term „uncertainty” in country reports of the Economist Intelligence Unit. Source and description: Ahir et al. (2018).

Empirical standard deviation of the i) log-level or ii) changes in the log-level of the daily nominal exchange rate of the German currency (DM/EUR) vis-à-vis the USD. Data sources: Bundesbank (Codes: BBEX3.D.USD.DEM.AA.AC.000; BBEX3.D.USD.EUR.BB.AC.000)

Quarterly average of Germany's daily forward premium given by $(F-S) / S$, where $S$ is the spot rate and $F$ the 3-month forward rate (DM/USD until 1998; then EUR/USD). An FP > 0 indicates an expected \$ appreciation. Data sources: Bundesbank (Codes: BBK01.ST0268; BBK01.ST0316), Datastream (Codes: WG90DUS; TDEUR3M).

Normalized number of newspaper articles related to geopolitical risk in 11 large US and international newspapers. Source and detailed description: Caldara and Iacoviello (2018).

Germany's general government balance as percentage of nominal GDP, both in national currency. Seasonally adjusted. Two outliers have both been replaced by linearly interpolated values to match the mean of the last $(\mathrm{t}-1)$ and the following $(\mathrm{t}+1)$ quarter: In 1995Q1 the German government assumed liabilities of the Treuhandanstalt (an agency charged with liquidating assets formerly owned by the East German government). In 2000Q3 extraordinary revenue was generated by auctioning of UMTS-licences. Data source: Federal Statistical Office (Destatis).

The difference between the German and US annualized inflation rate in percentage points. Annualized inflation rates in percentage points and based on the quarter-to-quarter relative change in the consumer price index. Data source: IMF's International Financial Statistics (Code: PCPI_PC_PP_PT). 
Money Growth M1 (M3)

Nominal GDP

PSI - Deauville Meeting

PSI - Greece

Interest Rate Differential

Redenomination Risk

Relative Money M1 (M3)

Rel. M1 (M3) Growth

Real GDP Growth

Shadow Economy

World Bank Statistical

Capacity Score

Stock Volatility

Tax Ratio

Import Duties Ratio

Trade Openness

Violent Conflicts
Quarter-to-Quarter change of (seasonally adjusted) monetary aggregate M1 (M3, respectively) as percentage of nominal GDP (series in national currency). Data source: OECD (Finance).

Gross Domestic Product at current prices. Derived from expenditure approach and seasonally adjusted. Data sources: Federal Statistical Office (Destatis).

A dummy variable, given by the indicator function $I(t>=2010 \mathrm{Q} 4\})$.

A dummy variable, given by the indicator function $I(t>=2012 \mathrm{Q} 1\})$.

Quarterly average of the daily interest rate differential given by $\left(r-r^{*}\right) /\left(1+r^{*}\right)$, where $r$ is the relevant London interbank offer rate (DM-based until 1998; then EUR-based), $\mathrm{r}^{*}$ is the US\$ LIBOR. All as annualized three-month rates. Positive values of RDiff indicate a higher nominal return on investment in Germany. Data sources: ICE Benchmark Administration Ltd. via Datastream (B5DEM3M; B5EUR3M; B5USD3M).

Market-sentiment based measure of redenomination risks given by the volume of Google searches implying the term "euro breakup” relative to its maximum [index 11/2011=100] after 2004, zero before. Data source: Google Application Trends.

Monetary aggregate M1 (M3, respectively) of Germany relative to the US, both seasonally adjusted and in percentage of nominal GDP. After the Euro introduction Germany's monetary aggregates refers to its contribution to the euro area's total. Data sources: Bundesbank, OECD, US Federal Reserve.

Quarter-to-quarter change of the variable Relative Money M1 (M3). Data sources: Bundesbank, OECD, US Federal Reserve. Quarter-to-quarter growth rate of Germany's real GDP. Real GDP is derived from nominal GDP adjusted for changes in consumer prices and seasonal patterns. Data sources: Federal Statistical Office (Destatis), IMF's International Financial Statistics (Code: PCPI_IX).

Size of the informal economy expressed as a percentage of (official) nominal GDP. Source: Medina \& Schneider (2018).

Worldwide average of a composite score assessing the capacity of the country's statistical system. Based on the average score, each between 0-100, over 25 criteria (e.g. methodology, data sources, periodicity \& timelines). No data before 2004. Source: World Bank (Code: IQ.SCI.OVRL).

(Option-)implied stock market volatility. We use the VDAX for Germany, the VOXX for the euro area, and the VIX for the US. Quarterly averages of daily data. Data source: Datastream.

Sum of (seasonally adjusted) government revenue from taxes and social security contributions as a percentage of nominal GDP. Data source: Federal Statistical Office (Destatis).

Sum of tariffs and import VAT as a \% of the same period's value of imports. Annual data from 1991 to 1998 interpolated to quarterly frequency using cubic splines. Data sources: Ministry of Finance, Federal Statistical Office (Destatis).

Measure of de facto trade openness, given by the value of the total trade volume as a percentage of nominal GDP. Data source: IMF’s International Financial Statistics (Code: TXG_FOB_USD, TMG_CIF_USD).

(Logged) worldwide battle-related deaths. Converted to quarterly frequency using cubic splines. Source: World Bank (Code: VC.BTL.DETH). 
Appendix B: Additional Regression Tables I

Table B1: T2 - Greek Uncertainty (Subcomponents)

\begin{tabular}{|c|c|c|c|c|c|c|c|c|c|}
\hline Variables & (1) & $(2)$ & (3) & (4) & (5) & (6) & (7) & (8) & (9) \\
\hline CID & $\begin{array}{l}0.185 \\
(0.43)\end{array}$ & $\begin{array}{l}0.293 \\
(0.68)\end{array}$ & $\begin{array}{l}0.146 \\
(0.34)\end{array}$ & $\begin{array}{l}0.150 \\
(0.34)\end{array}$ & $\begin{array}{l}0.125 \\
(0.29)\end{array}$ & $\begin{array}{l}0.141 \\
(0.32)\end{array}$ & $\begin{array}{l}0.093 \\
(0.21)\end{array}$ & $\begin{array}{l}0.038 \\
(0.09)\end{array}$ & $\begin{array}{l}0.220 \\
(0.51)\end{array}$ \\
\hline Currency Misalignment & $\begin{array}{l}0.893 \\
(0.26)\end{array}$ & $\begin{array}{l}0.005 \\
(0.00)\end{array}$ & $\begin{array}{l}-0.457 \\
(0.13)\end{array}$ & $\begin{array}{l}1.446 \\
(0.41)\end{array}$ & $\begin{array}{l}0.819 \\
(0.24)\end{array}$ & $\begin{array}{l}1.544 \\
(0.44)\end{array}$ & $\begin{array}{l}2.052 \\
(0.56)\end{array}$ & $\begin{array}{l}0.053 \\
(0.02)\end{array}$ & $\begin{array}{l}1.240 \\
(0.36)\end{array}$ \\
\hline Gov. Debt & $\begin{array}{l}0.041 * * \\
(2.05)\end{array}$ & $\begin{array}{l}0.041^{* *} \\
(2.06)\end{array}$ & $\begin{array}{l}0.046^{* *} \\
(2.31)\end{array}$ & $\begin{array}{l}0.041 * \\
(1.89)\end{array}$ & $\begin{array}{l}0.042^{* *} \\
(2.04)\end{array}$ & $\begin{array}{l}0.027 \\
(1.24)\end{array}$ & $\begin{array}{l}0.038 * \\
(1.84)\end{array}$ & $\begin{array}{l}0.036^{*} \\
(1.83)\end{array}$ & $\begin{array}{l}0.037^{*} \\
(1.88)\end{array}$ \\
\hline D(EA Spread) & $\begin{array}{l}-0.984^{* * * *} \\
(4.18)\end{array}$ & $\begin{array}{l}-1.001^{* * *} \\
(4.36)\end{array}$ & $\begin{array}{l}-1.029 * * * \\
(4.61)\end{array}$ & $\begin{array}{l}-1.076^{* * *} \\
(4.49)\end{array}$ & $\begin{array}{l}-1.047^{* * *} \\
(4.48)\end{array}$ & $\begin{array}{l}-1.088^{* * * *} \\
(4.61)\end{array}$ & $\begin{array}{l}-1.184^{* * *} \\
(5.03)\end{array}$ & $\begin{array}{l}-1.065^{* * *} \\
(4.70)\end{array}$ & $\begin{array}{l}-0.989 * * * \\
(4.23)\end{array}$ \\
\hline Collateral Standards & $\begin{array}{l}-0.611^{*} \\
(1.96)\end{array}$ & $\begin{array}{l}-0.573^{*} \\
(1.84)\end{array}$ & $\begin{array}{l}-0.597 * \\
(1.94)\end{array}$ & $\begin{array}{l}-0.587 * \\
(1.80)\end{array}$ & $\begin{array}{l}-0.604^{*} \\
(1.91)\end{array}$ & $\begin{array}{l}-0.627^{*} \\
(1.96)\end{array}$ & $\begin{array}{l}-0.614^{*} \\
(1.91)\end{array}$ & $\begin{array}{l}-0.637^{* *} \\
(2.03)\end{array}$ & $\begin{array}{l}-0.610 * \\
(1.95)\end{array}$ \\
\hline Collateral (Idiosyn.) & $\begin{array}{l}-4.084 * * * \\
(3.85)\end{array}$ & $\begin{array}{l}-4.229 * * * \\
(3.99)\end{array}$ & $\begin{array}{l}-3.852^{* * *} \\
(3.69)\end{array}$ & $\begin{array}{l}-3.940 * * * \\
(3.64)\end{array}$ & $\begin{array}{l}-3.999 * * * \\
(3.73)\end{array}$ & $\begin{array}{l}-4.065^{* * * *} \\
(3.71)\end{array}$ & $\begin{array}{l}-3.754 * * * \\
(3.38)\end{array}$ & $\begin{array}{l}-4.046^{* * * *} \\
(3.80)\end{array}$ & $\begin{array}{l}-4.145 * * * \\
(3.90)\end{array}$ \\
\hline $\begin{array}{l}\text { EU Policy Uncertainty } \\
\text { (Expert) }\end{array}$ & $\begin{array}{l}-0.006^{*} \\
(1.95) \\
\end{array}$ & $\begin{array}{l}-0.008^{* *} \\
(2.44)\end{array}$ & $\begin{array}{l}-0.008^{* * *} \\
(2.72)\end{array}$ & $\begin{array}{l}-0.008^{* *} \\
(2.54)\end{array}$ & $\begin{array}{l}-0.007 * * \\
(2.21)\end{array}$ & $\begin{array}{l}-0.008^{* *} \\
(2.60)\end{array}$ & $\begin{array}{l}-0.009^{* * *} \\
(2.76)\end{array}$ & $\begin{array}{l}-0.006^{*} \\
(1.83) \\
\end{array}$ & $\begin{array}{l}-0.007^{* *} \\
(2.02)\end{array}$ \\
\hline \multicolumn{10}{|c|}{ GREECE - ECONOMIC POLICy UNCERTAINTy (EPU) } \\
\hline EPU (all) & $\begin{array}{l}-0.011^{*} \\
(1.96)\end{array}$ & & & & & & & & \\
\hline EPU (Banking) & & $\begin{array}{l}-0.011^{* *} \\
(2.15)\end{array}$ & & & & & & & \\
\hline EPU (Currency) & & & $\begin{array}{l}-0.007 * * \\
(2.42)\end{array}$ & & & & & & \\
\hline EPU (Debt) & & & & $\begin{array}{l}-0.003 \\
(0.82)\end{array}$ & & & & & \\
\hline EPU (Fiscal) & & & & & $\begin{array}{l}-0.008 \\
(1.44)\end{array}$ & & & & \\
\hline EPU (Monetary) & & & & & & $\begin{array}{l}-0.004 \\
(0.79)\end{array}$ & & & \\
\hline EPU (Pension) & & & & & & & $\begin{array}{l}0.003 \\
(0.79)\end{array}$ & & \\
\hline EPU (Tax) & & & & & & & & $\begin{array}{l}-0.010^{*} \\
(1.78)\end{array}$ & \\
\hline $\begin{array}{l}\text { Economic Uncertainty } \\
\text { (broad) }\end{array}$ & & & & & & & & & $\begin{array}{l}-0.011^{* *} \\
(2.01) \\
\end{array}$ \\
\hline Constant & $\begin{array}{l}-1.279 \\
(0.88)\end{array}$ & $\begin{array}{l}-1.264 \\
(0.88)\end{array}$ & $\begin{array}{l}-1.801 \\
(1.27)\end{array}$ & $\begin{array}{l}-1.827 \\
(1.23)\end{array}$ & $\begin{array}{l}-1.601 \\
(1.10)\end{array}$ & $\begin{array}{l}-0.876 \\
(0.49)\end{array}$ & $\begin{array}{l}-2.100 \\
(1.34)\end{array}$ & $\begin{array}{l}-1.101 \\
(0.74)\end{array}$ & $\begin{array}{l}-0.984 \\
(0.67)\end{array}$ \\
\hline R-Squared (adj) & 0.50 & 0.51 & 0.52 & 0.48 & 0.49 & 0.48 & 0.48 & 0.50 & 0.50 \\
\hline Observations & 76 & 76 & 76 & 76 & 76 & 76 & 76 & 76 & 76 \\
\hline
\end{tabular}


Table B2: T2 - Economic Policy Uncertainty and Bailout Expectations

\begin{tabular}{|c|c|c|c|c|c|c|c|c|c|}
\hline & \multicolumn{9}{|c|}{ ECONOMIC POLICY UNCERTAINTY (EPU) MEASURE } \\
\hline & $\begin{array}{l}\text { EU EPU } \\
\text { (Expert) }\end{array}$ & $\begin{array}{l}\text { EU EPU } \\
\text { (News) }\end{array}$ & $\begin{array}{l}\text { PCA } \\
\text { (Expert) }\end{array}$ & $\begin{array}{l}\text { PCA News } \\
\text { (News) }\end{array}$ & $\begin{array}{l}\text { Greece EPU } \\
\text { (Expert) }\end{array}$ & $\begin{array}{l}\text { Ireland } \\
\text { EPU } \\
\text { (Expert)) }\end{array}$ & $\begin{array}{l}\text { Italy EPU } \\
\text { (Expert) }\end{array}$ & $\begin{array}{l}\text { Portugal } \\
\text { EPU } \\
\text { (Expert) }\end{array}$ & $\begin{array}{l}\text { Spain EPU } \\
\text { (Expert) }\end{array}$ \\
\hline Variables & $(1)$ & $(2)$ & $(3)$ & $(4)$ & $(5)$ & $(6)$ & $(7)$ & $(8)$ & $(9)$ \\
\hline CID & $\begin{array}{l}0.109 \\
(0.25)\end{array}$ & $\begin{array}{l}0.220 \\
(0.48)\end{array}$ & $\begin{array}{l}0.131 \\
(0.30)\end{array}$ & $\begin{array}{l}0.269 \\
(0.58)\end{array}$ & $\begin{array}{l}0.177 \\
(0.41)\end{array}$ & $\begin{array}{l}0.193 \\
(0.41)\end{array}$ & $\begin{array}{l}0.332 \\
(0.72)\end{array}$ & $\begin{array}{l}-0.087 \\
(0.19)\end{array}$ & $\begin{array}{l}0.339 \\
(0.71)\end{array}$ \\
\hline Currency Misalignment & $\begin{array}{l}0.694 \\
(0.15)\end{array}$ & $\begin{array}{l}3.912 \\
(0.82)\end{array}$ & $\begin{array}{l}1.119 \\
(0.24)\end{array}$ & $\begin{array}{l}3.698 \\
(0.77)\end{array}$ & $\begin{array}{l}1.046 \\
(0.23)\end{array}$ & $\begin{array}{l}3.351 \\
(0.69)\end{array}$ & $\begin{array}{l}4.206 \\
(0.92)\end{array}$ & $\begin{array}{l}3.125 \\
(0.66)\end{array}$ & $\begin{array}{l}4.239 \\
(0.92)\end{array}$ \\
\hline Gov. Debt & $\begin{array}{l}0.030 \\
(1.26)\end{array}$ & $\begin{array}{l}0.033 \\
(1.32)\end{array}$ & $\begin{array}{l}0.031 \\
(1.33)\end{array}$ & $\begin{array}{l}0.031 \\
(1.26)\end{array}$ & $\begin{array}{l}0.047 * \\
(1.94)\end{array}$ & $\begin{array}{l}0.037 \\
(1.49)\end{array}$ & $\begin{array}{l}0.046^{*} \\
(1.96)\end{array}$ & $\begin{array}{l}0.045^{*} \\
(1.87)\end{array}$ & $\begin{array}{l}0.039 \\
(1.59)\end{array}$ \\
\hline D(EA Spread) & $\begin{array}{l}-1.149 * * * \\
(4.97)\end{array}$ & $\begin{array}{l}-1.049 * * * \\
(4.41)\end{array}$ & $\begin{array}{l}-1.216^{* * *} \\
(5.22)\end{array}$ & $\begin{array}{l}-1.028^{* * *} \\
(4.34)\end{array}$ & $\begin{array}{l}-0.936^{* * *} \\
(4.13)\end{array}$ & $\begin{array}{l}-1.198^{* * *} \\
(4.67)\end{array}$ & $\begin{array}{l}-1.336^{* * *} \\
(5.17)\end{array}$ & $\begin{array}{l}-1.108^{* * *} \\
(4.61)\end{array}$ & $\begin{array}{l}-1.048^{* * * *} \\
(4.44)\end{array}$ \\
\hline Collateral Standards & $\begin{array}{l}-0.667 * * \\
(2.07)\end{array}$ & $\begin{array}{l}-0.468 \\
(1.37)\end{array}$ & $\begin{array}{l}-0.686^{* *} \\
(2.14)\end{array}$ & $\begin{array}{l}-0.428 \\
(1.24)\end{array}$ & $\begin{array}{l}-0.897 * * * \\
(2.78)\end{array}$ & $\begin{array}{l}-0.606^{*} \\
(1.78)\end{array}$ & $\begin{array}{l}-0.620^{*} \\
(1.90)\end{array}$ & $\begin{array}{l}-0.484 \\
(1.39)\end{array}$ & $\begin{array}{l}-0.765^{* *} \\
(2.28)\end{array}$ \\
\hline Collateral (Idiosyncratic) & $\begin{array}{l}-3.971^{* * *} \\
(3.64)\end{array}$ & $\begin{array}{l}-3.954^{* * *} \\
(3.53)\end{array}$ & $\begin{array}{l}-4.132^{* * *} \\
(3.81)\end{array}$ & $\begin{array}{l}-4.096^{* * *} \\
(3.64)\end{array}$ & $\begin{array}{l}-3.543^{* * *} \\
(3.33)\end{array}$ & $\begin{array}{l}-3.514^{* * *} \\
(3.07)\end{array}$ & $\begin{array}{l}-4.092^{* * *} \\
(3.68)\end{array}$ & $\begin{array}{l}-3.858^{* * *} \\
(3.40)\end{array}$ & $\begin{array}{l}-4.241 * * * \\
(3.71)\end{array}$ \\
\hline PSI (Deauville) & $\begin{array}{l}1.130 \\
(1.05)\end{array}$ & $\begin{array}{l}1.193 \\
(0.98)\end{array}$ & $\begin{array}{l}0.221 \\
(0.38)\end{array}$ & $\begin{array}{l}0.191 \\
(0.31)\end{array}$ & $\begin{array}{l}0.286 \\
(0.50)\end{array}$ & $\begin{array}{l}-0.031 \\
(0.05)\end{array}$ & $\begin{array}{l}0.474 \\
(0.72)\end{array}$ & $\begin{array}{l}0.102 \\
(0.15)\end{array}$ & $\begin{array}{l}0.138 \\
(0.20)\end{array}$ \\
\hline $\operatorname{EU} \operatorname{EPU}\left(\gamma_{1}\right)$ & $\begin{array}{l}-0.002 \\
(0.43)\end{array}$ & $\begin{array}{l}-0.002 \\
(0.52)\end{array}$ & $\begin{array}{l}-0.094 \\
(0.46)\end{array}$ & $\begin{array}{l}-0.094 \\
(0.61)\end{array}$ & $\begin{array}{l}0.593 \\
(0.52)\end{array}$ & $\begin{array}{l}-0.395 \\
(0.55)\end{array}$ & $\begin{array}{l}0.275 \\
(0.31)\end{array}$ & $\begin{array}{l}-0.124 \\
(0.10)\end{array}$ & $\begin{array}{l}-0.452 \\
(0.41)\end{array}$ \\
\hline PSI X EU EPU $\left(\gamma_{2}\right)$ & $\begin{array}{l}-0.009 \\
(1.27) \\
\end{array}$ & $\begin{array}{l}-0.007 \\
(1.11) \\
\end{array}$ & $\begin{array}{l}-0.360 \\
(1.42) \\
\end{array}$ & $\begin{array}{l}-0.224 \\
(1.15) \\
\end{array}$ & $\begin{array}{l}-4.153^{* * *} \\
(2.71)\end{array}$ & $\begin{array}{l}-1.267 \\
(1.00) \\
\end{array}$ & $\begin{array}{l}-3.322^{* *} \\
(2.18) \\
\end{array}$ & $\begin{array}{l}-2.480 \\
(1.26) \\
\end{array}$ & $\begin{array}{l}-1.823 \\
(1.17) \\
\end{array}$ \\
\hline EU EPU total $\left(\gamma_{1}+\gamma_{2}\right)$ & $\begin{array}{l}-0.011^{* * *} \\
(2.84)\end{array}$ & $\begin{array}{l}-0.009^{* *} \\
(2.18)\end{array}$ & $\begin{array}{l}-0.453^{* * *} \\
(3.05)\end{array}$ & $\begin{array}{l}-0.317 * * \\
(2.27) \\
\end{array}$ & $\begin{array}{l}-3.560^{* * *} \\
(3.37)\end{array}$ & $\begin{array}{l}-1.661 \\
(1.49)\end{array}$ & $\begin{array}{l}-3.048 * * \\
(2.47) \\
\end{array}$ & $\begin{array}{l}-2.605 \\
(1.66)\end{array}$ & $\begin{array}{l}-2.275^{* *} \\
(2.06) \\
\end{array}$ \\
\hline Constant & $\begin{array}{l}-1.970 \\
(1.20) \\
\end{array}$ & $\begin{array}{l}-2.365 \\
(1.48) \\
\end{array}$ & $\begin{array}{l}-2.455 \\
(1.59) \\
\end{array}$ & $\begin{array}{l}-2.564 \\
(1.62) \\
\end{array}$ & $\begin{array}{l}-3.421^{* *} \\
(2.14) \\
\end{array}$ & $\begin{array}{l}-2.737 \\
(1.65) \\
\end{array}$ & $\begin{array}{l}-3.535^{* *} \\
(2.29) \\
\end{array}$ & $\begin{array}{l}-3.291^{* *} \\
(2.05)\end{array}$ & $\begin{array}{l}-2.993 * \\
(1.92) \\
\end{array}$ \\
\hline $\begin{array}{l}\text { R-Squared (adj) } \\
\text { Observations }\end{array}$ & $\begin{array}{l}0.48 \\
76\end{array}$ & $\begin{array}{l}0.45 \\
76\end{array}$ & $\begin{array}{l}0.49 \\
76\end{array}$ & $\begin{array}{l}0.45 \\
76\end{array}$ & $\begin{array}{l}0.50 \\
76\end{array}$ & $\begin{array}{l}0.43 \\
76\end{array}$ & $\begin{array}{l}0.46 \\
76\end{array}$ & $\begin{array}{l}0.43 \\
76\end{array}$ & $\begin{array}{l}0.45 \\
76\end{array}$ \\
\hline
\end{tabular}

Notes: OLS estimates with t-statistics in parentheses. All specifications include quarterly dummies (not reported). *, **, *** indicate variables significant at $10 \%, 5 \%$, and $1 \%$ level respectively. 
Table B3: Different Adjustments to TARGET2

\begin{tabular}{|c|c|c|c|c|c|}
\hline & $\begin{array}{l}\text { T2 (defined in } \\
\text { eq. (4)) }\end{array}$ & $-(\triangle T A R G E T 2)$ & $\begin{array}{l}-(\triangle T A R G E T 2) \\
+C A^{E A}\end{array}$ & $\begin{array}{l}-(\triangle T A R G E T 2) \\
+C A P^{E A}+F A^{E A, G o v}\end{array}$ & T2, Restricted \\
\hline Variables & $(1)$ & $(2)$ & (3) & (4) & (5) \\
\hline \multirow[t]{2}{*}{ CID } & 0.150 & -0.217 & 0.034 & -0.101 & 0.185 \\
\hline & $(0.34)$ & $(0.51)$ & $(0.08)$ & $(0.22)$ & $(0.49)$ \\
\hline \multirow[t]{2}{*}{ Currency Misalignment } & 1.186 & -0.702 & 1.259 & -0.775 & 0.204 \\
\hline & $(0.34)$ & $(0.21)$ & $(0.39)$ & $(0.21)$ & $(0.07)$ \\
\hline \multirow[t]{2}{*}{ Gov. Debt } & $0.035^{*}$ & 0.010 & $0.034 *$ & 0.011 & 0.023 \\
\hline & $(1.72)$ & $(0.51)$ & $(1.82)$ & $(0.51)$ & $(1.32)$ \\
\hline \multirow[t]{2}{*}{ D(EA Spread) } & $-1.136 * * *$ & $-1.194 * * *$ & $-1.129 * * *$ & $-1.201 * * *$ & $-0.997 * * *$ \\
\hline & $(5.00)$ & $(5.47)$ & (5.39) & $(5.07)$ & $(5.12)$ \\
\hline \multirow[t]{2}{*}{ Collateral Standards } & $-0.641 * *$ & -0.439 & $-0.600 * *$ & -0.481 & $-0.534^{*}$ \\
\hline & $(2.01)$ & $(1.43)$ & $(2.04)$ & $(1.45)$ & $(1.96)$ \\
\hline \multirow[t]{2}{*}{ Collateral (Idiosyncratic) } & $-3.946 * * *$ & $-3.797 * * *$ & $-3.982 * * *$ & $-3.761 * * *$ & $-3.695 * * *$ \\
\hline & $(3.65)$ & (3.66) & (3.99) & (3.34) & (3.99) \\
\hline \multirow[t]{2}{*}{ EU Policy Uncertainty } & $-0.008 * * *$ & $-0.008 * * *$ & $-0.008 * * *$ & $-0.009 * * *$ & $-0.006 * *$ \\
\hline & $(2.66)$ & $(2.76)$ & $(2.74)$ & $(2.67)$ & $(2.10)$ \\
\hline \multirow[t]{2}{*}{ Constant } & -1.675 & -0.144 & -1.597 & -0.222 & -1.320 \\
\hline & $(1.14)$ & $(0.10)$ & $(1.18)$ & $(0.14)$ & $(1.05)$ \\
\hline R-Squared (adj) & 0.48 & 0.50 & 0.52 & 0.46 & 0.47 \\
\hline Observations & 76 & 76 & 76 & 76 & 76 \\
\hline
\end{tabular}

Notes: OLS estimates with t-statistics in parentheses. All specifications include quarterly dummies (not reported). * $* *, * * *$ indicate variables significant at $10 \%, 5 \%$, and $1 \%$ level respectively. 
Table B4: T2 - (Extended) Assets Purchase Programme by the Eurosystem

\begin{tabular}{|c|c|c|c|c|}
\hline Variables & $(1)$ & $(2)$ & (3) & $(4)$ \\
\hline \multirow[t]{2}{*}{ CID } & 0.186 & 0.169 & 0.213 & 0.244 \\
\hline & $(0.39)$ & $(0.37)$ & $(0.42)$ & $(0.51)$ \\
\hline \multirow[t]{2}{*}{ Currency Misalignment } & 0.687 & 0.883 & 0.510 & 0.303 \\
\hline & $(0.16)$ & $(0.23)$ & $(0.12)$ & $(0.08)$ \\
\hline \multirow[t]{2}{*}{ Gov. Debt } & 0.032 & 0.033 & 0.032 & 0.033 \\
\hline & (1.38) & $(1.40)$ & $(1.38)$ & $(1.41)$ \\
\hline \multirow[t]{2}{*}{ D(EA Spread) } & $-1.135 * * *$ & $-1.135 * * *$ & $-1.138 * * *$ & $-1.147 * * *$ \\
\hline & $(4.96)$ & $(4.96)$ & $(4.92)$ & $(4.96)$ \\
\hline \multirow[t]{2}{*}{ Collateral Standards $\left(\mu_{1}\right)$} & $-0.656 * *$ & $-0.642 * *$ & $-0.687^{*}$ & $-0.729 * *$ \\
\hline & $(2.00)$ & $(2.00)$ & $(1.81)$ & $(2.06)$ \\
\hline \multirow[t]{2}{*}{ Collateral (Idiosyncratic) } & $-3.964 * * *$ & $-3.961 * * *$ & $-3.961 * * *$ & $-3.952 * * *$ \\
\hline & $(3.63)$ & $(3.63)$ & $(3.60)$ & $(3.60)$ \\
\hline \multirow[t]{2}{*}{ EU Policy Uncertainty } & $-0.008 * *$ & $-0.008 * *$ & $-0.008 * *$ & $-0.009 * *$ \\
\hline & $(2.32)$ & $(2.19)$ & $(2.25)$ & $(2.26)$ \\
\hline \multirow[t]{2}{*}{ APP Dummy } & -0.127 & & -0.136 & \\
\hline & $(0.22)$ & & $(0.23)$ & \\
\hline \multirow[t]{2}{*}{ APP Monthly Purchases } & & -0.002 & & -0.003 \\
\hline & & $(0.18)$ & & $(0.34)$ \\
\hline \multirow[t]{2}{*}{ Collateral Standards X APP $\left(\mu_{2}\right)$} & & & 0.147 & 0.009 \\
\hline & & & $(0.16)$ & $(0.59)$ \\
\hline \multirow[t]{2}{*}{ Collateral Standards total $\left(\mu_{1}+\mu_{2}\right)$} & & & -0.540 & $-0.720 * *$ \\
\hline & & & $(0.69)$ & $(4.27)$ \\
\hline \multirow[t]{2}{*}{ Constant } & -1.539 & -1.570 & -1.541 & -1.527 \\
\hline & $(0.96)$ & $(0.99)$ & $(0.95)$ & $(0.96)$ \\
\hline R-Squared (adj) & 0.47 & 0.47 & 0.46 & 0.47 \\
\hline Observations & 76 & 76 & 76 & 76 \\
\hline
\end{tabular}

Notes: OLS estimates with t-statistics in parentheses. All specifications include quarterly dummies (not reported). *, **, *** indicate variables significant at $10 \%, 5 \%$, and $1 \%$ level respectively. 
Table C1: T2 - The Role of the Bail-ins as a Prerequisite for Bank Recapitalization

\begin{tabular}{llll}
\hline \hline Variables & $(1)$ & $(2)$ & $(3)$ \\
\hline CID & 0.188 & 0.141 & 0.152 \\
Currency Misalignment & $(0.43)$ & $(0.32)$ & $(0.34)$ \\
Gov. Debt & 3.583 & 0.010 & 0.318 \\
& $(0.81)$ & $(0.00)$ & $0.07)$ \\
D(EA Spread) & $0.039^{*}$ & 0.031 & $(1.40)$ \\
& $(1.88)$ & $(1.41)$ & $-1.123^{* * *}$ \\
Collateral Standards & $-1.139^{* * *}$ & $-1.123^{* * *}$ & $(4.82)$ \\
& $(5.01)$ & $(4.87)$ & $-0.646^{* *}$ \\
Collateral (Idiosyncratic) & $-0.642^{* *}$ & $-0.648^{* *}$ & $(2.01)$ \\
& $(2.01)$ & $(2.02)$ & $-3.981^{* * *}$ \\
EU EPU (Expert) & $-3.827^{* * *}$ & $-3.987^{* * *}$ & $(3.64)$ \\
& $(3.51)$ & $(3.65)$ & $-0.008^{* *}$ \\
\hline Bank Bail-in (1) & $-0.009^{* * *}$ & $-0.008^{* *}$ & $(2.42)$ \\
Bank Bail-in (2) & $(2.79)$ & $(2.37)$ & \\
Bank Bail-in (3) & 0.407 & & \\
\hline Constant & $(0.90)$ & & \\
\hline R-Squared (adj) & & -0.210 & $(0.43)$ \\
Observations & & & -0.154 \\
\hline \hline
\end{tabular}

Notes: OLS estimates with t-statistics in parentheses. All specifications include quarterly dummies (not reported). *, **, *** indicate variables significant at $10 \%, 5 \%$, and $1 \%$ level respectively. 
Table C2: T2 - Effect of the GFC

\begin{tabular}{|c|c|c|c|c|c|c|c|}
\hline Variables & $(1)$ & $(2)$ & (3) & $(4)$ & $(5)$ & $(6)$ & $(7)$ \\
\hline \multirow[t]{2}{*}{ CID } & -0.041 & 0.189 & 0.143 & 0.168 & 0.177 & 0.158 & -0.194 \\
\hline & $(0.06)$ & $(0.41)$ & $(0.31)$ & $(0.37)$ & $(0.39)$ & $(0.35)$ & $(0.25)$ \\
\hline \multirow[t]{2}{*}{ Currency Misalignment } & 0.721 & -4.104 & 0.025 & 0.819 & 0.565 & -0.426 & -6.888 \\
\hline & $(0.19)$ & $(0.60)$ & $(0.01)$ & $(0.21)$ & $(0.14)$ & $(0.11)$ & $(0.83)$ \\
\hline \multirow[t]{2}{*}{ Gov. Debt } & 0.041 & $0.047 *$ & 0.062 & 0.038 & 0.037 & 0.039 & 0.100 \\
\hline & $(1.52)$ & (1.68) & $(1.20)$ & $(1.40)$ & $(1.38)$ & $(1.47)$ & $(1.49)$ \\
\hline \multirow[t]{2}{*}{ D(EA Spread) } & $-1.150 * * *$ & $-1.145 * * *$ & $-1.130 * * *$ & -0.458 & $-1.132 * * *$ & $-1.158 * * *$ & -1.671 \\
\hline & $(4.86)$ & $(4.96)$ & $(4.89)$ & $(0.19)$ & $(4.89)$ & $(5.04)$ & $(0.62)$ \\
\hline \multirow[t]{2}{*}{ Collateral Standards } & $-0.626 *$ & $-0.665 *$ & -0.573 & $-0.618 *$ & -0.833 & $-0.603 *$ & -0.456 \\
\hline & $(1.88)$ & (1.99) & $(1.66)$ & $(1.86)$ & $(1.11)$ & (1.83) & $(0.56)$ \\
\hline \multirow[t]{2}{*}{ Collateral (Idiosyncratic) } & $-4.032 * * *$ & $-3.985 * * *$ & $-3.954 * * *$ & $-3.988 * * *$ & $-4.033 * * *$ & $-4.031 * * *$ & $-3.982 * * *$ \\
\hline & $(3.62)$ & $(3.61)$ & $(3.56)$ & (3.59) & $(3.61)$ & $(3.67)$ & $(3.47)$ \\
\hline \multirow[t]{2}{*}{ EU EPU (Expert) } & $-0.008 * *$ & $-0.007 * *$ & $-0.009 * *$ & $-0.008 * *$ & $-0.008 * *$ & -0.002 & -0.001 \\
\hline & $(2.54)$ & $(2.15)$ & $(2.61)$ & $(2.55)$ & $(2.57)$ & $(0.35)$ & $(0.21)$ \\
\hline \multirow[t]{2}{*}{ D08 } & -0.271 & -0.387 & 1.941 & -0.117 & -0.118 & 0.808 & 5.002 \\
\hline & $(0.45)$ & $(0.69)$ & $(0.48)$ & $(0.24)$ & $(0.25)$ & $(0.90)$ & $(1.00)$ \\
\hline \multirow[t]{2}{*}{ D08 X CID } & 0.357 & & & & & & 0.471 \\
\hline & $(0.38)$ & & & & & & $(0.48)$ \\
\hline \multirow[t]{2}{*}{ D08 X Currency Misalignment } & & 7.195 & & & & & 7.107 \\
\hline & & $(0.85)$ & & & & & $(0.72)$ \\
\hline \multirow[t]{2}{*}{ D08 X Gov. Debt } & & & -0.032 & & & & -0.071 \\
\hline & & & $(0.51)$ & & & & $(0.94)$ \\
\hline \multirow[t]{2}{*}{ D08 X D(EA Spread) } & & & & -0.678 & & & 0.477 \\
\hline & & & & $(0.28)$ & & & $(0.18)$ \\
\hline \multirow[t]{2}{*}{ D08 X Collateral Standards } & & & & & 0.267 & & -0.118 \\
\hline & & & & & $(0.32)$ & & $(0.13)$ \\
\hline \multirow[t]{2}{*}{ D08 X EU EPU (Expert) } & & & & & & -0.009 & -0.009 \\
\hline & & & & & & $(1.24)$ & $(1.19)$ \\
\hline \multirow[t]{2}{*}{ Constant } & -2.002 & -2.331 & -3.280 & -1.852 & -1.848 & -2.515 & -6.050 \\
\hline & $(1.11)$ & $(1.26)$ & $(1.04)$ & $(1.01)$ & $(1.01)$ & $(1.37)$ & $(1.46)$ \\
\hline R-Squared (adj) & 0.46 & 0.47 & 0.47 & 0.46 & 0.46 & 0.48 & 0.44 \\
\hline Observations & 76 & 76 & 76 & 76 & 76 & 76 & 76 \\
\hline
\end{tabular}

Notes: OLS estimates with t-statistics in parentheses. All specifications include quarterly dummies (not reported). *, **, *** indicate variables significant at $10 \%, 5 \%$, and $1 \%$ level respectively. 
Table C3: T2 - Effect of the Euro Crisis

\begin{tabular}{|c|c|c|c|c|c|c|c|}
\hline Variables & $(1)$ & $(2)$ & (3) & $(4)$ & $(5)$ & $(6)$ & $(7)$ \\
\hline \multirow[t]{2}{*}{ CID } & 0.010 & 0.173 & 0.147 & 0.152 & 0.157 & 0.116 & -0.108 \\
\hline & $(0.02)$ & $(0.39)$ & $(0.32)$ & $(0.33)$ & $(0.35)$ & $(0.26)$ & $(0.16)$ \\
\hline \multirow[t]{2}{*}{ Currency Misalignment } & -1.059 & -2.685 & -1.011 & -1.053 & -1.107 & -1.337 & -1.846 \\
\hline & $(0.19)$ & $(0.41)$ & $(0.19)$ & $(0.19)$ & $(0.20)$ & $(0.25)$ & $(0.26)$ \\
\hline \multirow[t]{2}{*}{ Gov. Debt } & 0.047 & 0.043 & 0.045 & 0.045 & 0.045 & 0.039 & 0.046 \\
\hline & $(1.64)$ & $(1.53)$ & $(1.22)$ & $(1.59)$ & $(1.61)$ & $(1.37)$ & $(1.18)$ \\
\hline \multirow[t]{2}{*}{ D(EA Spread) } & $-1.131 * * *$ & $-1.142^{* * *}$ & $-1.115 * * *$ & -1.158 & $-1.116 * * *$ & $-1.143^{* * *}$ & -1.006 \\
\hline & $(4.76)$ & $(4.75)$ & $(4.77)$ & $(1.34)$ & $(4.78)$ & $(4.92)$ & $(1.09)$ \\
\hline \multirow[t]{2}{*}{ Collateral Standards } & $-0.593^{*}$ & $-0.645^{*}$ & $-0.607 *$ & $-0.606^{*}$ & -0.656 & $-0.626^{*}$ & -0.603 \\
\hline & $(1.79)$ & $(1.90)$ & $(1.83)$ & $(1.84)$ & $(1.24)$ & (1.92) & $(1.08)$ \\
\hline \multirow[t]{2}{*}{ Collateral (Idiosyncratic) } & $-4.041 * * *$ & $-3.954 * * *$ & $-3.952 * * *$ & $-3.960 * * *$ & $-3.988 * * *$ & $-3.957 * * *$ & $-3.995 * * *$ \\
\hline & $(3.60)$ & $(3.61)$ & $(3.57)$ & $(3.58)$ & $(3.51)$ & $(3.65)$ & $(3.32)$ \\
\hline \multirow[t]{2}{*}{ EU EPU (Expert) } & $-0.008 * *$ & $-0.008 * *$ & $-0.008 * *$ & $-0.008 * *$ & $-0.008 * *$ & -0.003 & -0.002 \\
\hline & $(2.48)$ & $(2.26)$ & $(2.40)$ & $(2.51)$ & $(2.50)$ & $(0.44)$ & $(0.38)$ \\
\hline \multirow[t]{2}{*}{ D10 } & -0.528 & -0.305 & -0.361 & -0.383 & -0.394 & 0.690 & 1.602 \\
\hline & $(0.64)$ & $(0.42)$ & $(0.09)$ & $(0.53)$ & $(0.54)$ & $(0.61)$ & $(0.34)$ \\
\hline \multirow[t]{2}{*}{ D10 X CID } & 0.312 & & & & & & 0.424 \\
\hline & $(0.36)$ & & & & & & $(0.43)$ \\
\hline \multirow[t]{2}{*}{ D10 X Currency Misalignment } & & 4.665 & & & & & 1.981 \\
\hline & & $(0.45)$ & & & & & $(0.16)$ \\
\hline \multirow[t]{2}{*}{ D10 X Gov. Debt } & & & -0.000 & & & & -0.014 \\
\hline & & & $(0.00)$ & & & & $(0.23)$ \\
\hline \multirow[t]{2}{*}{ D10 X D(EA Spread) } & & & & 0.045 & & & -0.186 \\
\hline & & & & $(0.05)$ & & & $(0.19)$ \\
\hline \multirow[t]{2}{*}{ D10 X Collateral Standards } & & & & & 0.081 & & -0.027 \\
\hline & & & & & $(0.12)$ & & $(0.04)$ \\
\hline \multirow[t]{2}{*}{ D10 X EU EPU (Expert) } & & & & & & -0.008 & -0.008 \\
\hline & & & & & & $(1.19)$ & $(1.11)$ \\
\hline \multirow[t]{2}{*}{ Constant } & -2.336 & -2.117 & -2.238 & -2.248 & -2.248 & -2.411 & -2.807 \\
\hline & $(1.27)$ & $(1.15)$ & $(0.97)$ & $(1.22)$ & $(1.23)$ & (1.33) & $(1.15)$ \\
\hline Observations & 76 & 76 & 76 & 76 & 76 & 76 & 76 \\
\hline R-Squared (adj) & 0.47 & 0.47 & 0.46 & 0.46 & 0.47 & 0.48 & 0.43 \\
\hline
\end{tabular}

Notes: OLS estimates with t-statistics in parentheses. All specifications include quarterly dummies (not reported). * $* *, * * *$ indicate variables significant at $10 \%, 5 \%$, and $1 \%$ level respectively. 
Table C4: TMI - Effect of the GFC

\begin{tabular}{|c|c|c|c|c|c|c|c|c|}
\hline Variables & $(1)$ & $(2)$ & (3) & $(4)$ & (5) & (6) & $(7)$ & $(8)$ \\
\hline \multirow[t]{2}{*}{ CID } & -0.015 & -0.001 & -0.001 & 0.000 & -0.003 & -0.019 & -0.000 & -0.011 \\
\hline & $(0.21)$ & $(0.01)$ & $(0.02)$ & $(0.01)$ & $(0.07)$ & $(0.38)$ & $(0.01)$ & $(0.16)$ \\
\hline \multirow[t]{2}{*}{ Real GDP Growth } & $-0.012 *$ & -0.011 & $-0.012 *$ & -0.005 & -0.012 & -0.010 & $-0.012 *$ & -0.007 \\
\hline & $(1.77)$ & $(0.78)$ & $(1.79)$ & $(0.63)$ & $(1.61)$ & $(1.42)$ & $(1.78)$ & $(0.50)$ \\
\hline \multirow[t]{2}{*}{ Inflation Diff. } & $0.014^{*}$ & $0.014^{*}$ & 0.003 & $0.015 * *$ & $0.014^{*}$ & 0.010 & $0.014 *$ & -0.001 \\
\hline & $(1.85)$ & $(1.85)$ & $(0.26)$ & $(2.00)$ & $(1.87)$ & $(1.33)$ & $(1.79)$ & $(0.05)$ \\
\hline \multirow[t]{2}{*}{ Currency Misalignment } & $0.952 * * *$ & $0.942 * * *$ & $0.969 * * *$ & $0.655 * *$ & $1.003 * * *$ & $0.908 * * *$ & $0.952 * * *$ & 0.587 \\
\hline & $(3.43)$ & $(3.31)$ & $(3.53)$ & $(2.05)$ & (3.28) & (3.29) & $(3.40)$ & (1.56) \\
\hline \multirow[t]{2}{*}{ Gov. Debt } & $0.005 *$ & 0.005 & 0.005 & 0.004 & 0.008 & 0.005 & 0.005 & 0.002 \\
\hline & (1.68) & (1.66) & $(1.54)$ & (1.39) & (1.08) & (1.57) & (1.56) & $(0.20)$ \\
\hline \multirow[t]{2}{*}{ Exr. volatility } & $0.184 * *$ & $0.186^{* *}$ & $0.157^{*}$ & $0.157^{*}$ & $0.186 * *$ & 0.061 & $0.188 * *$ & 0.020 \\
\hline & $(2.27)$ & $(2.28)$ & (1.93) & (1.95) & $(2.33)$ & $(0.51)$ & $(2.35)$ & $(0.16)$ \\
\hline \multirow[t]{2}{*}{ Import Duties Ratio } & $-0.069 * *$ & $-0.068 * *$ & $-0.066 * *$ & $-0.066^{* *}$ & -0.057 & -0.054 & $-0.069 * *$ & -0.056 \\
\hline & $(2.22)$ & $(2.07)$ & $(2.14)$ & $(2.13)$ & $(1.34)$ & $(1.66)$ & $(2.03)$ & $(1.08)$ \\
\hline \multirow[t]{2}{*}{ D08 } & -0.020 & -0.008 & 0.015 & 0.005 & 0.213 & -0.135 & 0.005 & 0.015 \\
\hline & $(0.33)$ & $(0.15)$ & $(0.28)$ & $(0.11)$ & $(0.38)$ & (1.34) & $(0.01)$ & $(0.02)$ \\
\hline \multirow[t]{2}{*}{ D08 X CID } & 0.026 & & & & & & & 0.004 \\
\hline & $(0.28)$ & & & & & & & $(0.04)$ \\
\hline \multirow[t]{2}{*}{ D08 X Real GDP Growth } & & -0.002 & & & & & & 0.007 \\
\hline & & $(0.15)$ & & & & & & $(0.41)$ \\
\hline \multirow[t]{2}{*}{ D08 X Inflation Diff. } & & & 0.019 & & & & & $0.024 *$ \\
\hline & & & $(1.48)$ & & & & & $(1.78)$ \\
\hline \multirow[t]{2}{*}{ D08 X Currency Misalignment } & & & & $1.107^{*}$ & & & & $1.317 *$ \\
\hline & & & & $(1.76)$ & & & & $(1.86)$ \\
\hline \multirow[t]{2}{*}{ D08 X Gov. Debt } & & & & & -0.003 & & & 0.003 \\
\hline & & & & & $(0.40)$ & & & $(0.32)$ \\
\hline \multirow[t]{2}{*}{ D08 X Exr. volatility } & & & & & & 0.230 & & 0.183 \\
\hline & & & & & & $(1.41)$ & & $(1.04)$ \\
\hline \multirow[t]{2}{*}{ D08 X Import Duties Ratio } & & & & & & & -0.003 & -0.047 \\
\hline & & & & & & & $(0.03)$ & $(0.52)$ \\
\hline \multirow[t]{2}{*}{ Constant } & -0.368 & -0.379 & -0.359 & -0.314 & -0.605 & -0.366 & -0.373 & -0.139 \\
\hline & $(1.16)$ & $(1.16)$ & $(1.15)$ & $(1.00)$ & $(0.91)$ & $(1.17)$ & $(1.06)$ & $(0.18)$ \\
\hline R-Squared (adj) & 0.56 & 0.56 & 0.57 & 0.57 & 0.56 & 0.57 & 0.55 & 0.56 \\
\hline Observations & 92 & 92 & 92 & 92 & 92 & 92 & 92 & 92 \\
\hline
\end{tabular}

Observations $\quad 92 \quad 92 \quad 92 \quad 92$ $10 \%, 5 \%$, and $1 \%$ level respectively. 
Table C5: TMI - Effect of the Euro Crisis

\begin{tabular}{|c|c|c|c|c|c|c|c|c|}
\hline Variables & $(1)$ & $(2)$ & (3) & $(4)$ & (5) & (6) & $(7)$ & $(8)$ \\
\hline \multirow[t]{2}{*}{ CID } & 0.017 & 0.004 & 0.006 & 0.000 & 0.005 & 0.006 & 0.007 & 0.017 \\
\hline & $(0.27)$ & $(0.09)$ & $(0.13)$ & $(0.01)$ & $(0.10)$ & $(0.12)$ & $(0.14)$ & $(0.26)$ \\
\hline \multirow[t]{2}{*}{ Real GDP Growth } & -0.009 & -0.014 & -0.009 & -0.011 & -0.009 & -0.009 & -0.009 & -0.015 \\
\hline & (1.11) & $(1.60)$ & $(1.12)$ & $(1.36)$ & (1.12) & $(1.06)$ & (1.14) & $(1.54)$ \\
\hline \multirow[t]{2}{*}{ Inflation Diff. } & $0.014^{*}$ & $0.016 * *$ & 0.013 & $0.014^{*}$ & $0.015^{*}$ & $0.014 *$ & $0.015 *$ & 0.013 \\
\hline & $(1.86)$ & $(2.10)$ & $(1.66)$ & $(1.96)$ & $(1.95)$ & (1.91) & $(1.97)$ & $(1.56)$ \\
\hline \multirow[t]{2}{*}{ Currency Misalignment } & $0.857 * * *$ & $0.892 * * *$ & $0.859 * * *$ & $0.628 *$ & $0.858 * *$ & $0.857 * * *$ & $0.866 * * *$ & $0.654 *$ \\
\hline & (2.99) & (3.13) & $(3.00)$ & (1.93) & (2.59) & $(2.99)$ & $(3.00)$ & $(1.76)$ \\
\hline \multirow[t]{2}{*}{ Gov. Debt } & $0.006 * *$ & $0.007 * *$ & $0.006 * *$ & 0.004 & 0.007 & $0.007 * *$ & $0.007^{*}$ & 0.004 \\
\hline & $(2.00)$ & $(2.27)$ & $(2.04)$ & $(0.93)$ & (1.11) & $(2.00)$ & (1.97) & $(0.58)$ \\
\hline \multirow[t]{2}{*}{ Exr. volatility } & $0.178 * *$ & $0.148 *$ & $0.182 * *$ & $0.187 * *$ & $0.179 * *$ & $0.183^{* *}$ & $0.175 * *$ & $0.160 *$ \\
\hline & $(2.28)$ & $(1.84)$ & $(2.33)$ & $(2.43)$ & $(2.30)$ & $(2.07)$ & $(2.22)$ & $(1.70)$ \\
\hline \multirow[t]{2}{*}{ Import Duties Ratio } & $-0.061 *$ & -0.053 & $-0.062 *$ & $-0.080 * *$ & -0.062 & $-0.062 *$ & -0.058 & -0.071 \\
\hline & $(1.90)$ & $(1.63)$ & $(1.93)$ & $(2.35)$ & $(1.46)$ & $(1.93)$ & $(1.63)$ & $(1.48)$ \\
\hline \multirow[t]{2}{*}{ D10 } & & 0.024 & & & & & & 0.026 \\
\hline & & $(1.29)$ & & & & & & $(1.20)$ \\
\hline \multirow[t]{2}{*}{ D10 X CID } & & & 0.006 & & & & & 0.011 \\
\hline & & & $(0.40)$ & & & & & $(0.71)$ \\
\hline \multirow[t]{2}{*}{ D10 X Real GDP Growth } & & & & 1.333 & & & & 1.294 \\
\hline & & & & $(1.41)$ & & & & $(1.29)$ \\
\hline \multirow[t]{2}{*}{ D10 X Inflation Diff. } & & & & & -0.000 & & & 0.002 \\
\hline & & & & & $(0.01)$ & & & $(0.18)$ \\
\hline \multirow[t]{2}{*}{ D10 X Currency Misalignment } & & & & & & -0.015 & & -0.022 \\
\hline & & & & & & $(0.08)$ & & $(0.11)$ \\
\hline \multirow[t]{2}{*}{ D10 X Gov. Debt } & & & & & & & -0.025 & -0.022 \\
\hline & & & & & & & $(0.26)$ & $(0.21)$ \\
\hline \multirow[t]{2}{*}{ Constant } & -0.497 & $-0.584^{*}$ & -0.503 & -0.181 & -0.499 & -0.501 & -0.541 & -0.255 \\
\hline & $(1.44)$ & $(1.67)$ & $(1.45)$ & $(0.45)$ & $(0.83)$ & $(1.41)$ & (1.39) & $(0.37)$ \\
\hline R-Squared (adj) & 0.56 & 0.57 & 0.56 & 0.57 & 0.56 & 0.56 & 0.56 & 0.55 \\
\hline Observations & 92 & 92 & 92 & 92 & 92 & 92 & 92 & 92 \\
\hline
\end{tabular}


Table C6: T2 - CDS Spreads as alternative Measure of Country-risk

\begin{tabular}{llll}
\hline \hline & $\begin{array}{l}\text { Baseline } \\
\text { (full sample) }\end{array}$ & $\begin{array}{l}\text { CDS } \\
\left(2008^{*}\right)\end{array}$ & $\begin{array}{l}\text { Baseline } \\
\left(2008^{*}\right)\end{array}$ \\
\hline \hline Variables & $(1)$ & $(2)$ & $(3)$ \\
\hline CID & 0.150 & -0.544 & 0.323 \\
Currency Misalignment & $(0.34)$ & $(0.85)$ & $(0.45)$ \\
& 1.186 & 0.269 & 1.425 \\
Gov. Debt & $(0.34)$ & $(0.04)$ & $(0.23)$ \\
Collateral Standards & $0.035^{*}$ & 0.038 & 0.035 \\
& $(1.72)$ & $(0.93)$ & $(0.83)$ \\
Collateral (Idiosyncratic) & $-0.641^{* *}$ & -0.662 & $-0.871^{*}$ \\
EU EPU (Expert) & $(2.01)$ & $(1.49)$ & $(1.87)$ \\
& $-3.946^{* * *}$ & $-4.365^{* * *}$ & $-3.906^{* * *}$ \\
\hline D(EA Spread) & $(3.65)$ & $(3.59)$ & $(3.06)$ \\
& $-0.008^{* * *}$ & $-0.008^{*}$ & $-0.010^{* *}$ \\
D(CDS Spread) & $(2.66)$ & $(1.81)$ & $(2.19)$ \\
\hline Constant & $-1.136^{* * *}$ & & $-1.132^{* * *}$ \\
& $(5.00)$ & & $(4.29)$ \\
\hline R-Squared (adj) & & $-0.015^{* * *}$ & \\
\hline \hline Observations & -1.675 & $(4.74)$ & -1.142 \\
\hline
\end{tabular}

Notes: OLS estimates with t-statistics in parentheses. All specifications include quarterly dummies (not reported). *, **, *** indicate variables significant at 10\%, 5\%, and 1\% level respectively. 


\section{References}

Alesina, Alberto, and Guido Tabellini (1989). External debt, capital flight and political risk. Journal of international Economics 27(3-4), 199-220. https://doi.org/10.1016/00221996(89)90052-4.

Ahir, Hites, Nicholas Bloom, and Davide Furceri (2018). World Uncertainty Index. Stanford mimeo.

Auer, Raphael A. (2014). What drives TARGET2 balances? Evidence from a panel analysis. Economic Policy 29(77), 139-197. https://doi.org/10.1111/1468-0327.12024.

Baker, Scott R., Nicholas Bloom, and Steven J. Davis (2016). Measuring economic policy uncertainty. The Quarterly Journal of Economics 131(4), 1593-1636. https://doi.org/10.1093/qje/qjw024.

Beja Jr, Edsel L. (2008). Estimating Trade Mis-invoicing from China: 2000-2005. China \& World Economy 16(2), 82-92. https://doi.org/10.1111/j.1749-124X.2008.00108.x.

Bhagwati, Jagdish N., Anne Krueger, and Chaiyawat Wibulswasdi (1974). Capital flight from LDCs: A statistical analysis. In: Bhagwati, Jagdish N. (ed.). Illegal transactions in international trade. North-Holland, 148-154. https://doi.org/10.1016/B978-0-44410581-3.50017-3.

Bhagwati, Jagdish N. (1981). Alternative theories of illegal trade: Economic consequences and statistical detection. Weltwirtschaftliches Archiv 117(3), 409-427. https://doi.org/10.1007/BF02706100.

Bhagwati, Jagdish N. (1964). On the underinvoicing of imports. Oxford Bulletin of Economics and Statistics 27(4), 389-397. https://doi.org/10.1016/B978-0-444-10581-3.50016-1.

Boyce, James K., and Léonce Ndikumana (2001). Is Africa a net creditor? New estimates of capital flight from severely indebted sub-Saharan African countries, 1970-96. Journal of Development Studies 38(2), 27-56. https://doi.org/10.1080/00220380412331322261.

Buehn, Andreas and Stefan Eichler (2011). Trade misinvoicing: The dark side of world trade. The World Economy 34(8), 1263-1287. https://doi.org/10.1111/j.14679701.2011.01375.x.

Caldara, Dario and Matteo Iacoviello (2018). Measuring Geopolitical Risk. Board of Governors of the Federal Reserve System, International Finance Discussion Papers \#1222. https://doi.org/10.17016/IFDP.2018.1222.

Cardoso, Eliana and Rüdiger Dornbusch (1989). Foreign private capital flows. In: Handbook of Development Economics 2, 1387-1439. https://doi.org/10.1016/S15734471(89)02013-9.

Cecchetti, Stephen G., Robert N. McCauley and Patrick M. McGuire (2012). Interpreting Target2 Balances. Bank for International Settlements Working Paper No. 393.

Cecioni, Martina, and Giuseppe Ferrero (2012). Determinants of TARGET2 imbalances. Bank of Italy Occasional Paper 136. http://dx.doi.org/10.2139/ssrn.2176227.

Cerra, Valerie, Meenakshi Rishi, and Sweta C. Saxena (2008). Robbing the riches: capital flight, institutions and debt. Journal of Development Studies 44(8), 1190-1213. https://doi.org/10.1080/00220380802242453.

Cheung, Yin-Wong, and XingWang Qian (2010). Capital flight: China's experience. Review of Development Economics 14(2), 227-247. https://doi.org/10.1111/j.14679361.2010.00549.x.

Cheung, Yin-W ong, Kenneth K. Chow, and Matthew S. Yiu (2017). Effects of capital flow on the equity and housing markets in Hong Kong. Pacific Economic Review 22(3), 332349. https://doi.org/10.1111/1468-0106.12233.

Cheung, Yin-Wong, Sven Steinkamp, and Frank Westermann (2016). China's capital flight: Pre-and post-crisis experiences. Journal of International Money and Finance 66, 88112. https://doi.org/10.1016/j.jimonfin.2015.12.009. 
Claessens, Stijn and David Naude (1993). Recent Estimates of Capital Flight. World Bank Policy Research Working Paper Series, No. 1186.

Collier, Paul, Anke Hoeffler, and Catherine Pattillo (2001). Flight Capital as a Portfolio Choice. World Bank Economic Review 15(1), 55-80. https://doi.org/10.1093/wber/15.1.55.

Collier, Paul, Anke Hoeffler, and Catherine Pattillo (2004). Africa's exodus: Capital flight and the brain drain as portfolio decisions. Journal of African Economies 13(2), 15-54. https://doi.org/10.1093/jae/ejh042.

Couharde, Cécile, Anne-Laure Delatte, Carl Grekou, Valérie Mignon, and Florian Morvillier (2018). Eqchange: A world database on actual and equilibrium effective exchange rates. International Economics 156, 206-230. https://doi.org/10.1016/j.inteco.2018.03.004

Cuddington, John T. (1986). Capital flight: Estimates, issues, and explanations, Princeton Studies in International Finance, No. 58.

Cuddington, John T. (1987). Capital flight. European Economic Review 31(1-2), 382-388. https://doi.org/10.1016/0014-2921(87)90055-9.

De Beaufort Wijnholds, J. Onno and Arend Kapteyn (2001). International Reserve Adequacy in Emerging Market Economies. IMF Working Paper 01/43.

De Grauwe, Paul, and Yuemei Ji (2012). What Germany should fear most is its own fear: An analysis of Target2 and current account imbalances. CEPS Working documents No. 368.

De Grauwe, Paul, Yuemei Ji, and Corrado Macchiarelli (2017). TARGET (im)balances at record level: Should we worry? In-depth analysis for the European Parliament, Directorate General For Internal Policies, IP/A/ECON/2017-04.

Diwan, Ishac (1989). Foreign debt, crowding out and capital flight. Journal of International Money and Finance 8(1), 121-136. https://doi.org/10.1016/0261-5606(89)90018-1.

Drechsler, Itamar, Thomas Drechsel, David Marques-Ibanez, and Philipp Schnabl (2016). Who borrows from the lender of last resort? The Journal of Finance 71(5), 1933-1974. https://doi.org/10.1111/jofi.12421.

Dornbusch, Rüdiger (1984). External debt, budget deficits and disequilibrium exchange rates, NBER Working Papers, No. 1336. https://doi.org/10.3386/w1336.

Eberl, Jakob, and Christopher Weber (2014). ECB collateral criteria: A narrative database 2001-2013. Ifo Working Paper No. 174.

Eisenschmidt, Jens, Danielle Kedan, Martin Schmitz, Ramón Adalid, and Patrick Papsdorf (2017). The Eurosystem's asset purchase programme and TARGET balances. ECB Occasional Paper No. 196.

Epstein, Gerald A. (2005). Capital flight and capital controls in developing countries. Edward Elgar Publishing.

Financial Action Task Force (2010). Mutual Evaluation Report - Germany - Anti-Money Laundering and Combating the Financing of Terrorism. OECD and IMF, February 2010.

Financial Action Task Force (2014). Mutual Evaluation Report - Germany - $3^{\text {rd }}$ follow-up report. OECD and IMF, June 2014.

Fisman, Raymond and Shang-Jin Wei (2004). Tax rates and tax evasion: evidence from "missing imports" in China. Journal of Political Economy 112(2), 471-496. https://doi.org/10.1086/381476.

Fedderke, Johannes W. and Wenyu Liu (2002). Modelling the determinants of capital flows and capital flight: with an application to South African data from 1960 to 1995. Economic Modelling 19(3), 419-444. https://doi.org/10.1016/S0264-9993(01)00071-2.

Felbermayr, Gabriel, Clemens Fuest, and Timo Wollmershäuser (2017). The German current account surplus: where does it come from, is it harmful and should Germany do something about it? In: Beck, Thorsten and Hans-Helmut (eds.). Ordoliberalism: A German oddity? CEPR Press, London, 2017, 187-199. 
Ferrantino, Michael J., Xuepeng Liu, and Zhi Wang (2012). Evasion behaviors of exporters and importers: Evidence from the US-China trade data discrepancy. Journal of international Economics 86(1), 141-157. https://doi.org/10.1016/j.jinteco.2011.08.006.

Garber, Peter M. (1999). The Target mechanism: will it propagate or stifle a Stage III crisis? Carnegie-Rochester Conference Series on Public Policy 51(1), 195-220. https://doi.org/10.1016/S0167-2231(00)00010-5.

Garber, Peter M. (2010). The Mechanics of Intra Euro Capital Flight. DB Economics Special Report, 10 December 2010.

Gaulier, Guillaume and Soledad Zignago (2019). BACI: International Trade Database at the Product-level. The 1994-2007 Version. CEPII Working Paper No. 2010-23.

He, Zhiguo, Arvind Krishnamurthy, and Konstantin Milbradt (2019). A model of safe asset determination. American Economic Review 109(4), 1230-1262. https://doi.org/10.1257/aer.20160216.

Hermes, Niels and Robert Lensink (2001). Capital flight and the uncertainty of government policies. Economics letters 71(3), 377-381. https://doi.org/10.1016/S01651765(01)00392-5.

Hummels, David (2007). Transportation costs and international trade in the second era of globalization. Journal of Economic Perspectives 21(3), 131-154. https://doi.org/10.1257/jep.21.3.131.

International Monetary Fund (2015). Direction of Trade Statistics Quarterly. Washington, DC. Jacks, David S., Christopher M. Meissner, and Dennis Novy (2008). Trade Costs, 1870-2000. American Economic Review 98(2), 529-34. https://doi.org/10.1257/aer.98.2.529.

Javorcik, Beata S. and Gaia Narciso (2008). Differentiated products and evasion of import tariffs. Journal of International Economics 76(2), 208-222. https://doi.org/10.1016/j.jinteco.2008.07.002.

Kant, Chander (1996). Foreign direct investment and capital flight. Princeton Studies in International Finance, No. 80.

Kar, Dev and Devon Cartwright-Smith (2009). Illicit financial flows from developing countries: 2002-2006. Global Financial Integrity. Washington, DC.

Kar, Dev and Sarah Freitas (2012). Illicit Financial Flows from China and the Role of Trade Misinvoicing. Global Financial Integrity. Washington, DC.

Kellenberg, Derek and Arik Levinson (2019). Misreporting trade: Tariff evasion, corruption, and auditing standards. Review of International Economics 27(1), 106-129. https://doi.org/10.1111/roie.12363.

Kollmann, Robert, Marco Ratto, Werner Roeger, Jan in 't Veld, and Lukas Vogel (2015). What drives the German current account? And how does it affect other EU member states? Economic Policy 30(81), 47-93. https://doi.org/10.1093/epolic/eiu004.

Le, Quan Vu, and Paul J. Zak (2006). Political risk and capital flight. Journal of International Money and Finance 25(2), 308-329. https://doi.org/10.1016/j.jimonfin.2005.11.001.

Lensink, Robert, Niels Hermes, and Victor Murinde (1998). The effect of financial liberalization on capital flight in African economies. World Development 26(7), 13491368. https://doi.org/10.1016/S0305-750X(98)00042-4.

Lensink, Robert, Niels Hermes, and Victor Murinde (2000). Capital flight and political risk. Journal of international Money and Finance 19(1), 73-92. https://doi.org/10.1016/S0261-5606(99)00034-0.

Medina, Leandro, and Friedrich Schneider (2018). Shadow Economies Around the World: What Did We Learn Over the Last 20 Years? IMF Working Papers 18/17, International Monetary Fund.

Miao, Guannan, and Fabienne Fortanier (2017). Estimating Transport and Insurance Costs of International Trade. OECD Statistics Working Paper, No. 2017/04. 
Mikkelsen, Jan Giehm (1991). An econometric investigation of capital flight. Applied Economics 23(1), 73-85. https://doi.org/10.1080/00036849108841050.

Mishra, Prachi, Arvind Subramanian, and Petia Topalova (2008). Tariffs, enforcement, and customs evasion: Evidence from India. Journal of public Economics 92(10-11), 19071925. https://doi.org/10.1016/j.jpubeco.2008.04.017.

Mody, Ashoka (2013). Sovereign debt and its restructuring framework in the eurozone. Oxford Review of Economic Policy 29(4), 715-744. https://doi.org/10.1057/9781137304957_10.

Obstfeld, Maurice, Jay C. Shambaugh, and Alan M. Taylor (2009). Financial instability, reserves, and central bank swap lines in the panic of 2008. American Economic Review 99(2), 480-86. https://doi.org/10.1257/aer.99.2.480.

OECD (2018). Estimating transport and insurance costs of international trade - 2018 update. OECD Statistical note.

Patnaik, Ila, Abhijit Sen Gupta, and Ajay Shah (2012). Determinants of trade misinvoicing. Open Economies Review 23(5), 891-910. https://doi.org/10.1007/s11079-011-9214-4.

Reinhart, Carmen (2016). Fleeing from Italy. Project Syndicate, 23 November 2016.

Sachs, Jeffrey, Aaron Tornell, and Andrés Velasco (1996). The Mexican peso crisis: Sudden death or death foretold? Journal of International Economics 41(3-4), 265-283. https://doi.org/10.1016/S0022-1996(96)01437-7.

Schäfer, Alexander, Isabel Schnabel, and B. Weder di Mauro. (2017). Expecting Bail-in? Evidence from European Banks. CEPR Discussion Paper No. 11061.

Schneider, Benu (2003). Measuring capital flight: estimates and interpretations. Overseas Development Institute Working Paper, No. 194.

Sinn, Hans-Werner and Timo Wollmershäuser (2012). Target loans, current account balances and capital flows: the ECB's rescue facility. International Tax and Public Finance 19(4), 468-508. https://doi.org/10.1007/s10797-012-9236-x.

Steiner, Andreas, Sven Steinkamp, and Frank Westermann (2019). Exit Strategies, Capital Flight and Speculative Attacks: Europe's Version of the Trilemma. European Journal of Political Economy, forthcoming. https://doi.org/10.1016/j.ejpoleco.2019.02.003.

Wei, Shang-Jin, Jianhuan Xu, and Jungho Lee (2018). An Unhealthy Trade Surplus. mimeo.

Westermann, Frank (2014). Discussion of: TARGET2 and central bank balance sheets. Economic Policy 29(77), 117-125.

Whelan, Karl (2014). TARGET2 and central bank balance sheets. Economic Policy 29(77), 79-116. https://doi.org/10.1111/1468-0327.12025.

Worku, Temesgen, Juan P. Mendoza, and Jacco L. Wielhouwer (2016). Tariff evasion in subSaharan Africa: the influence of corruption in importing and exporting countries. International Tax and Public Finance 23(4), 741-761. https://doi.org/10.1007/s10797016-9407-2. 


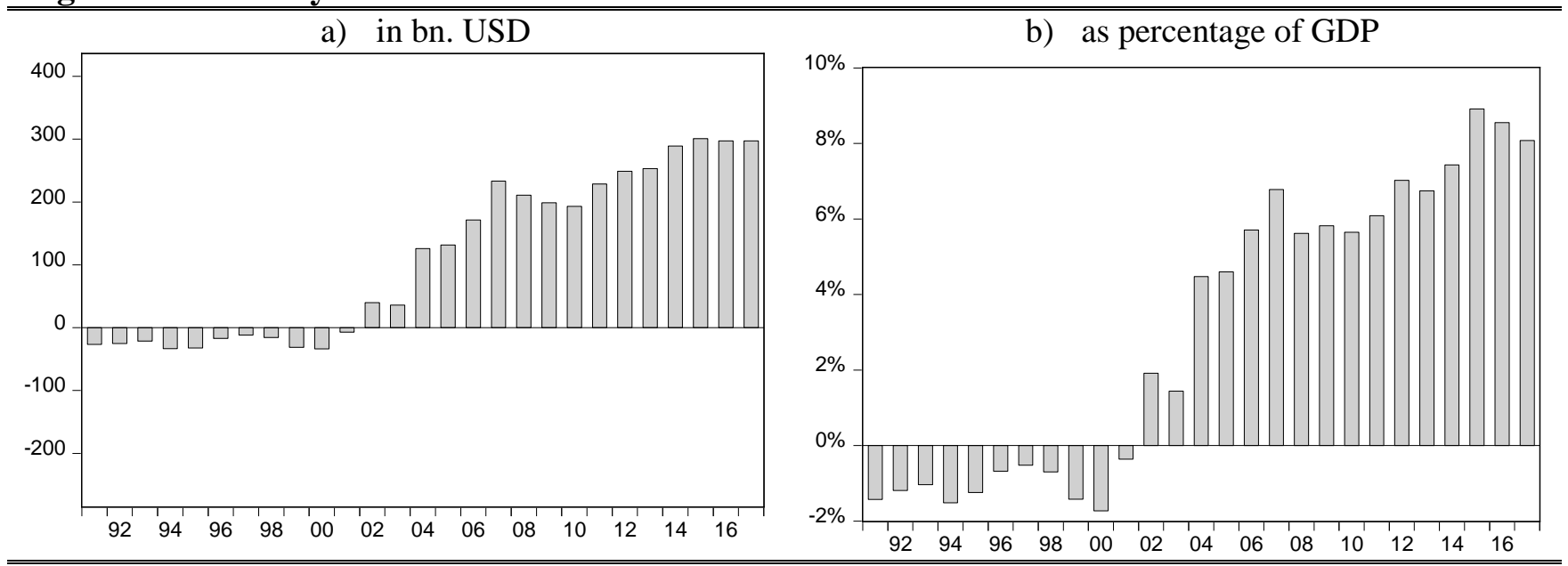

Data sources: World Bank WDI (Codes: BN.CAB.XOKA.CD; BN.CAB.XOKA.GD.ZS).

\section{Figure 2: Capital Flight Measures}

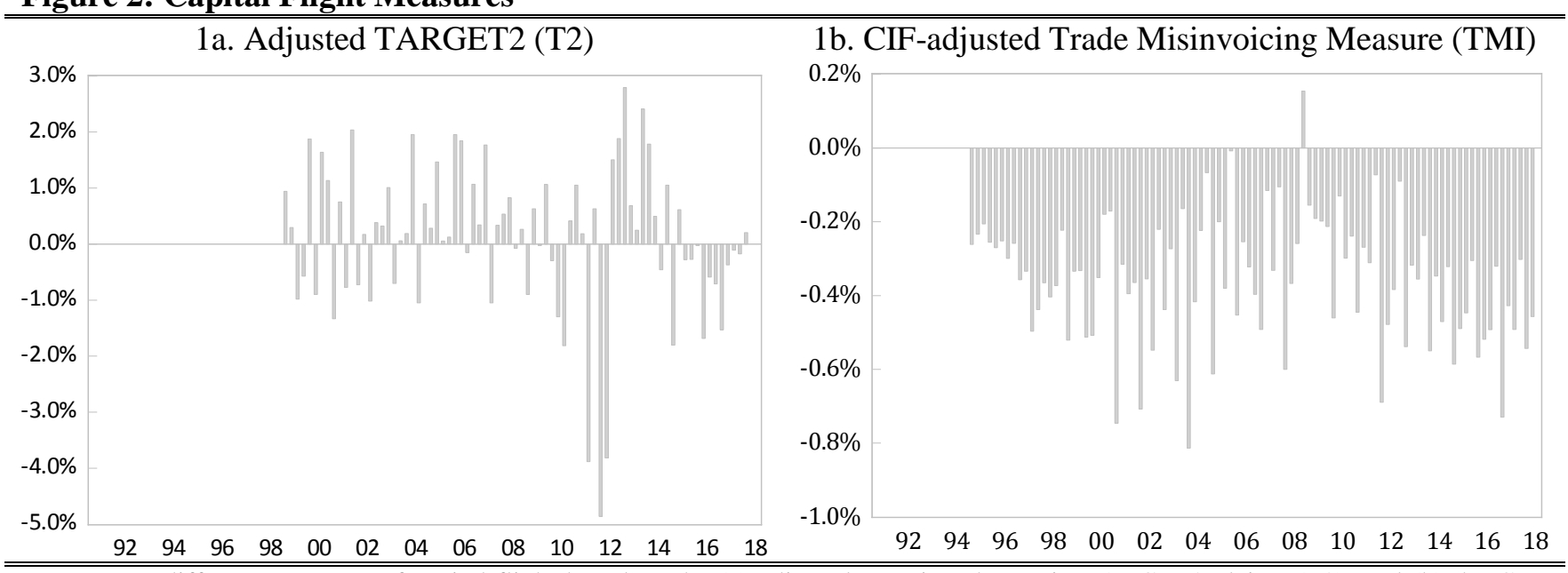

Notes: Two different measures of capital flight based on the (a) adjusted negative change in TARGET2-claims (T2), and (b) the CIFadjusted trade misinvoicing method. Both series as percentage of (annualized) nominal GDP. See data appendix for details on definitions and data sources. 


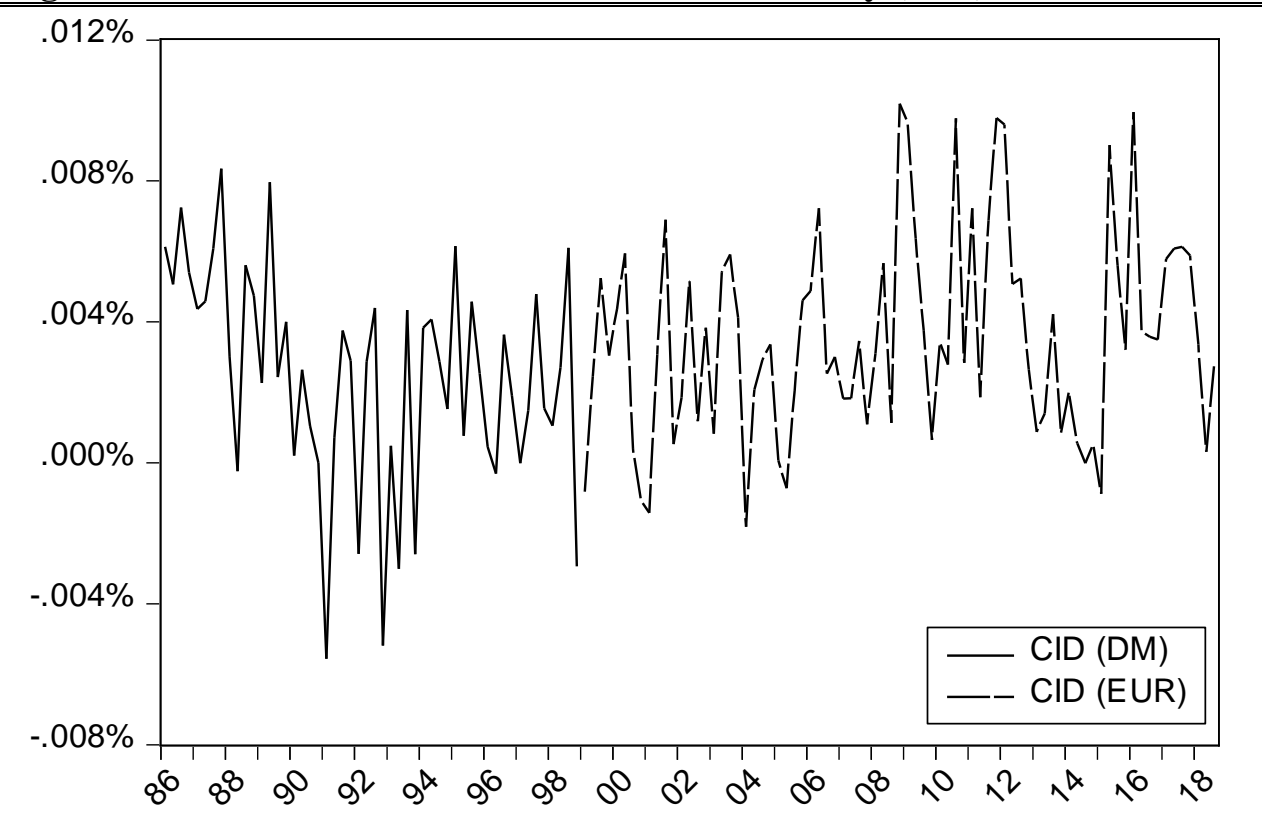

Notes: Quarterly average of Germany's daily covered interest differentials (blue: DM; red: EUR). It is given by the nominal interest rate differential (RDiff) plus the forward premium $(F P)$, i.e. CID $=R$ Diff $+F P=\left(r-r^{*}\right) /\left(1+r^{*}\right)+(F-S) / S$, where $r$ is the London interbank offer rate (DM-based until 1998; then EUR-based), $r^{*}$ is the US\$ LIBOR, $F$ is the forward rate and $S$ is the spot exchange rate (DM/USD until 1998; then EUR/USD). $r, r^{*}$ and $F$ are annualized three-month rates in daily frequency. Data sources: Bundesbank (Codes: BBK01.ST0268; BBK01.ST0316); ICE Benchmark Administration Ltd. via Datastream (B5DEM3M; B5EUR3M; B5USD3M), Datastream (Codes: WG90DUS; TDEUR3M).

Table 1: Unit Root Tests

\begin{tabular}{|c|c|c|c|}
\hline \multirow[b]{3}{*}{ Variable } & DF-GLS & $\begin{array}{l}\text { PHILLIPS-PERRON } \\
\end{array}$ & \multirow[b]{3}{*}{ Sample } \\
\hline & \multicolumn{2}{|c|}{$\overline{\text { H0: Has a Unit Root }}$} & \\
\hline & t-stat & Adj. t-stat & \\
\hline$\overline{\mathrm{T} 2}$ & $-7.022 * * *$ & $-7.806^{* * *}$ & 1999Q1-2018q3 (Full/Common) \\
\hline TMI & $\begin{array}{l}-1.978^{* *} \\
-2.390^{* *}\end{array}$ & $\begin{array}{l}-10.316^{* * *} \\
-9.761^{* * *}\end{array}$ & \begin{tabular}{|l} 
1996Q1-2018q3 (Full) \\
1999Q1-2018q3 (Common)
\end{tabular} \\
\hline
\end{tabular}

Notes: All specifications include a constant (and no deterministic trend). AR(p)-choice in Dickey-Fuller (DF) tests is based on the SIC. Phillips-Perron (PP) tests based on Bartlettkernel estimation with Newey-West automatic bandwidth selection. 
Table 2: Determinants of TMI - Baseline Results

\begin{tabular}{|c|c|c|c|c|c|c|}
\hline & $\begin{array}{l}\text { Arbitrage } \\
\text { Motive }\end{array}$ & $\begin{array}{l}\text { Canonical } \\
\text { Fundamentals } \\
\end{array}$ & $\begin{array}{l}\text { Monetary } \\
\text { Factors } \\
\end{array}$ & $\begin{array}{l}\text { Measure- } \\
\text { specific } \\
\end{array}$ & Full & Stepwise \\
\hline Variables & $(1)$ & $(2)$ & (3) & (4) & $(5)$ & $(6)$ \\
\hline CID & $\begin{array}{l}0.054 \\
(1.12) \\
\end{array}$ & $\begin{array}{l}0.038 \\
(0.80) \\
\end{array}$ & $\begin{array}{l}0.043 \\
(0.89) \\
\end{array}$ & $\begin{array}{l}0.034 \\
(0.62) \\
\end{array}$ & $\begin{array}{l}0.012 \\
(0.22) \\
\end{array}$ & $\begin{array}{l}-0.002 \\
(0.04)\end{array}$ \\
\hline Real GDP Growth & & $\begin{array}{l}-0.014^{*} \\
(1.96)\end{array}$ & & & $\begin{array}{l}-0.010 \\
(1.13)\end{array}$ & $\begin{array}{l}-0.012^{*} \\
(1.80)\end{array}$ \\
\hline Inflation Diff. & & $\begin{array}{l}0.015 * \\
(1.97)\end{array}$ & & & $\begin{array}{l}0.013 \\
(1.63)\end{array}$ & $\begin{array}{l}0.014^{*} \\
(1.88)\end{array}$ \\
\hline Currency Misalignment & & $\begin{array}{l}1.119 * * * \\
(3.71)\end{array}$ & & & $\begin{array}{l}1.117^{* *} \\
(2.35)\end{array}$ & $\begin{array}{l}0.975^{* * *} \\
(3.92)\end{array}$ \\
\hline Gov. Debt & & $\begin{array}{l}0.007 * * * \\
(2.79)\end{array}$ & & & $\begin{array}{l}0.003 \\
(0.70)\end{array}$ & $\begin{array}{l}0.005^{*} \\
(1.95)\end{array}$ \\
\hline Gov. Bal. & & $\begin{array}{l}0.003 \\
(0.37)\end{array}$ & & & $\begin{array}{l}0.002 \\
(0.12)\end{array}$ & \\
\hline Tax Ratio & & $\begin{array}{l}0.001 \\
(0.04)\end{array}$ & & & $\begin{array}{l}0.004 \\
(0.22)\end{array}$ & \\
\hline Stock Volatility (VDAX) & & $\begin{array}{l}0.000 \\
(0.10)\end{array}$ & & & $\begin{array}{l}-0.000 \\
(0.13)\end{array}$ & \\
\hline Rel. M1 Growth & & & $\begin{array}{l}0.203 * * \\
(2.01)\end{array}$ & & $\begin{array}{l}0.130 \\
(1.16)\end{array}$ & \\
\hline Rel. M3 Growth & & & $\begin{array}{l}-0.236 \\
(1.30)\end{array}$ & & $\begin{array}{l}-0.259 \\
(1.19)\end{array}$ & \\
\hline Exr. volatility & & & & $\begin{array}{l}0.224^{* *} \\
(2.60)\end{array}$ & $\begin{array}{l}0.147 \\
(1.57)\end{array}$ & $\begin{array}{l}0.184^{* *} \\
(2.40)\end{array}$ \\
\hline Import Duties Ratio & & & & $\begin{array}{l}-0.116^{* * *} \\
(3.47)\end{array}$ & $\begin{array}{l}-0.062 \\
(1.52)\end{array}$ & $\begin{array}{l}-0.069 * * \\
(2.24)\end{array}$ \\
\hline Shadow Economy & & & & $\begin{array}{l}0.016^{* *} \\
(2.19)\end{array}$ & $\begin{array}{l}-0.008 \\
(0.30)\end{array}$ & \\
\hline D(Trade Openness) & & & & $\begin{array}{l}-0.005 \\
(0.63)\end{array}$ & $\begin{array}{l}0.004 \\
(0.51)\end{array}$ & \\
\hline Constant & $\begin{array}{l}-0.389 * * * \\
(11.31)\end{array}$ & $\begin{array}{l}-0.856 \\
(1.22) \\
\end{array}$ & $\begin{array}{l}-0.392 * * * \\
(11.54)\end{array}$ & $\begin{array}{l}0.050 \\
(0.27) \\
\end{array}$ & $\begin{array}{l}-0.352 \\
(0.47) \\
\end{array}$ & $\begin{array}{l}-0.350 \\
(1.16) \\
\end{array}$ \\
\hline $\begin{array}{l}\text { R-Squared (adj) } \\
\text { Observations }\end{array}$ & $\begin{array}{l}0.39 \\
94\end{array}$ & $\begin{array}{l}0.52 \\
92\end{array}$ & $\begin{array}{l}0.41 \\
94\end{array}$ & $\begin{array}{l}0.48 \\
84 \\
\end{array}$ & $\begin{array}{l}0.50 \\
84\end{array}$ & $\begin{array}{l}0.57 \\
92\end{array}$ \\
\hline
\end{tabular}

Notes: OLS estimates with t-statistics in parentheses. All specifications include quarterly dummies (not reported). * $* *, * * *$ indicate variables significant at 10\%, 5\%, and 1\% level respectively. 
Table 3: Determinants of T2 - Baseline Results

\begin{tabular}{|c|c|c|c|c|c|c|}
\hline & $\begin{array}{l}\text { Arbitrage } \\
\text { Motive }\end{array}$ & $\begin{array}{l}\text { Canonical } \\
\text { Fundamentals }\end{array}$ & $\begin{array}{l}\text { Monetary } \\
\text { Factors }\end{array}$ & $\begin{array}{l}\text { Measure- } \\
\text { specific }\end{array}$ & Full & Stepwise \\
\hline Variables & $(1)$ & $(2)$ & (3) & (4) & (5) & (6) \\
\hline CID & $\begin{array}{l}-1.321^{* * * *} \\
(2.65)\end{array}$ & $\begin{array}{l}-0.925 \\
(1.64)\end{array}$ & $\begin{array}{l}-1.399 * * * \\
(2.74)\end{array}$ & $\begin{array}{l}-0.153 \\
(0.32)\end{array}$ & $\begin{array}{l}0.168 \\
(0.33)\end{array}$ & $\begin{array}{l}-0.002 \\
(0.00)\end{array}$ \\
\hline Real GDP Growth & & $\begin{array}{l}-0.035 \\
(0.38)\end{array}$ & & & $\begin{array}{l}0.059 \\
(0.68)\end{array}$ & \\
\hline Inflation Diff. & & $\begin{array}{l}-0.048 \\
(0.50)\end{array}$ & & & $\begin{array}{l}-0.009 \\
(0.11)\end{array}$ & \\
\hline Currency Misalignment & & $\begin{array}{l}3.340 \\
(0.72)\end{array}$ & & & $\begin{array}{l}8.347^{*} \\
(1.97)\end{array}$ & $\begin{array}{l}7.146^{* *} \\
(2.56)\end{array}$ \\
\hline Gov. Debt & & $\begin{array}{l}-0.002 \\
(0.09)\end{array}$ & & & $\begin{array}{l}0.037 \\
(1.40)\end{array}$ & $\begin{array}{l}0.037 * \\
(1.76)\end{array}$ \\
\hline Gov. Bal. & & $\begin{array}{l}0.000 \\
(0.00)\end{array}$ & & & $\begin{array}{l}-0.016 \\
(0.16)\end{array}$ & \\
\hline Tax Ratio & & $\begin{array}{l}-0.029 \\
(0.16)\end{array}$ & & & $\begin{array}{l}-0.024 \\
(0.15)\end{array}$ & \\
\hline Stock Volatility (VDAX) & & $\begin{array}{l}-0.027 \\
(1.42)\end{array}$ & & & $\begin{array}{l}-0.013 \\
(0.74)\end{array}$ & \\
\hline Rel. M1 Growth & & & $\begin{array}{l}0.896 \\
(0.84)\end{array}$ & & $\begin{array}{l}0.663 \\
(0.64)\end{array}$ & \\
\hline Rel. M3 Growth & & & $\begin{array}{l}-0.980 \\
(0.48)\end{array}$ & & $\begin{array}{l}-1.914 \\
(0.85)\end{array}$ & \\
\hline D(EA Spread) & & & & $\begin{array}{l}-0.888 * * * \\
(3.66)\end{array}$ & $\begin{array}{l}-1.018 * * * \\
(3.62)\end{array}$ & $\begin{array}{l}-1.025^{* * *} \\
(4.40)\end{array}$ \\
\hline D(Redenomination Risk) & & & & $\begin{array}{l}-0.004 \\
(0.39)\end{array}$ & $\begin{array}{l}-0.004 \\
(0.36)\end{array}$ & \\
\hline Collateral Standards & & & & $\begin{array}{l}-0.497 \\
(1.42)\end{array}$ & $\begin{array}{l}-0.645 \\
(1.58)\end{array}$ & $\begin{array}{l}-0.667 * * \\
(2.00)\end{array}$ \\
\hline Collateral (idiosyncratic) & & & & $\begin{array}{l}-3.700 * * * \\
(3.19)\end{array}$ & $\begin{array}{l}-3.587^{* * *} \\
(2.89)\end{array}$ & $\begin{array}{l}-3.795^{* * * *} \\
(3.36)\end{array}$ \\
\hline Constant & $\begin{array}{l}0.034 \\
(0.10)\end{array}$ & $\begin{array}{l}2.031 \\
(0.23)\end{array}$ & $\begin{array}{l}0.032 \\
(0.09)\end{array}$ & $\begin{array}{l}-0.345 \\
(1.13)\end{array}$ & $\begin{array}{l}-1.733 \\
(0.22)\end{array}$ & $\begin{array}{l}-2.935^{* *} \\
(2.02)\end{array}$ \\
\hline R-Squared (adj) & 0.13 & 0.09 & 0.11 & 0.38 & 0.38 & 0.43 \\
\hline Observations & 77 & 76 & 77 & 77 & 76 & 76 \\
\hline
\end{tabular}


Table 4: T2 - The Role of EU Economic Policy Uncertainty

\begin{tabular}{|c|c|c|c|c|c|c|c|c|c|}
\hline Variables & $(1)$ & $(2)$ & (3) & $(4)$ & $(5)$ & $(6)$ & $(7)$ & $(8)$ & (9) \\
\hline \multirow[t]{2}{*}{ CID } & 0.150 & 0.184 & 0.250 & 0.187 & 0.075 & 0.087 & 0.107 & -0.042 & 0.252 \\
\hline & $(0.34)$ & $(0.41)$ & $(0.54)$ & $(0.42)$ & $(0.17)$ & $(0.19)$ & $(0.23)$ & $(0.09)$ & $(0.54)$ \\
\hline \multirow{2}{*}{ Currency Misalignment } & 1.186 & 2.841 & 2.689 & 0.911 & 3.667 & $5.494 *$ & $6.437 * *$ & $5.667 *$ & $6.298 * *$ \\
\hline & $(0.34)$ & $(0.82)$ & $(0.78)$ & $(0.26)$ & $(1.15)$ & $(1.77)$ & $(2.28)$ & $(1.85)$ & $(2.26)$ \\
\hline \multirow[t]{2}{*}{ Gov. Debt } & $0.035^{*}$ & $0.041^{*}$ & $0.036^{*}$ & $0.040 * *$ & 0.029 & 0.030 & $0.038 *$ & $0.035^{*}$ & $0.039 *$ \\
\hline & $(1.72)$ & (1.99) & $(1.77)$ & $(2.02)$ & $(1.40)$ & $(1.38)$ & $(1.83)$ & (1.69) & (1.89) \\
\hline D(EA Spread) & $\begin{array}{l}-1.136^{* * * *} \\
(5.00)\end{array}$ & $\begin{array}{l}-1.013^{* * * *} \\
(4.45)\end{array}$ & $\begin{array}{l}-0.999 * * * \\
(4.39)\end{array}$ & $\begin{array}{l}-1.199 * * * \\
(5.20)\end{array}$ & $\begin{array}{l}-1.007 * * * \\
(4.43)\end{array}$ & $\begin{array}{l}-1.092^{* * * *} \\
(4.57)\end{array}$ & $\begin{array}{l}-1.120 * * * \\
(4.60)\end{array}$ & $\begin{array}{l}-1.046^{* * * *} \\
(4.48)\end{array}$ & $\begin{array}{l}-1.010^{* * * *} \\
(4.40)\end{array}$ \\
\hline Collateral Standards & $\begin{array}{l}-0.641^{* *} \\
(2.01)\end{array}$ & $\begin{array}{l}-0.474 \\
(1.40)\end{array}$ & $\begin{array}{l}-0.429 \\
(1.25)\end{array}$ & $\begin{array}{l}-0.630 * \\
(1.99)\end{array}$ & $\begin{array}{l}-0.765^{* *} \\
(2.33)\end{array}$ & $\begin{array}{l}-0.606^{*} \\
(1.81)\end{array}$ & $\begin{array}{l}-0.669 * * \\
(2.02)\end{array}$ & $\begin{array}{l}-0.600^{*} \\
(1.78)\end{array}$ & $\begin{array}{l}-0.749 * * \\
(2.26)\end{array}$ \\
\hline Collateral (Idiosyncratic) & $\begin{array}{l}-3.946^{* * *} \\
(3.65)\end{array}$ & $\begin{array}{l}-3.974 * * * \\
(3.59)\end{array}$ & $\begin{array}{l}-4.096^{* * * *} \\
(3.69)\end{array}$ & $\begin{array}{l}-4.034^{* * *} \\
(3.75)\end{array}$ & $\begin{array}{l}-3.583^{* * * *} \\
(3.25)\end{array}$ & $\begin{array}{l}-3.676^{* * *} \\
(3.26)\end{array}$ & $\begin{array}{l}-3.876^{* * *} \\
(3.45)\end{array}$ & $\begin{array}{l}-3.834^{* * *} \\
(3.41)\end{array}$ & $\begin{array}{l}-4.148^{* * *} \\
(3.68)\end{array}$ \\
\hline EU EPU (Expert) & $\begin{array}{l}-0.008^{* * *} \\
(2.66)\end{array}$ & & & & & & & & \\
\hline EU EPU (News) & & $\begin{array}{l}-0.006^{* *} \\
(2.04)\end{array}$ & & & & & & & \\
\hline \multicolumn{10}{|l|}{ PRINCIPAL COMPONENTS } \\
\hline \multicolumn{2}{|l|}{ PCA Expert (Global, EU, DE) } & & $\begin{array}{l}-0.218^{* *} \\
(2.10)\end{array}$ & & & & & & \\
\hline \multicolumn{2}{|l|}{ PCA News (Global, EU, DE) } & & & $\begin{array}{l}-0.315^{* * *} \\
(2.81)\end{array}$ & & & & & \\
\hline \multicolumn{10}{|c|}{ COUNTRY-LEVEL SUBCOMPONENTS } \\
\hline Greece EPU (Expert) & & & & & $\begin{array}{l}-1.692^{* *} \\
(2.11)\end{array}$ & & & & \\
\hline \multicolumn{2}{|l|}{ Ireland EPU (Expert)) } & & & & & $\begin{array}{l}-0.746 \\
(1.20)\end{array}$ & & & \\
\hline \multicolumn{2}{|l|}{ Italy EPU (Expert) } & & & & & & $\begin{array}{l}-0.899 \\
(1.28)\end{array}$ & & \\
\hline \multicolumn{2}{|l|}{ Portugal EPU (Expert) } & & & & & & & $\begin{array}{l}-1.088 \\
(1.14)\end{array}$ & \\
\hline Spain EPU (Expert) & & & & & & & & & $\begin{array}{l}-1.383^{*} \\
(1.78) \\
\end{array}$ \\
\hline Constant & $\begin{array}{l}-1.675 \\
(1.14) \\
\end{array}$ & $\begin{array}{l}-2.451^{*} \\
(1.70) \\
\end{array}$ & $\begin{array}{l}-2.995^{* *} \\
(2.11)\end{array}$ & $\begin{array}{l}-3.223^{* *} \\
(2.33)\end{array}$ & $\begin{array}{l}-2.163 \\
(1.48) \\
\end{array}$ & $\begin{array}{l}-2.308 \\
(1.50) \\
\end{array}$ & $\begin{array}{l}-2.893^{* *} \\
(2.00)\end{array}$ & $\begin{array}{l}-2.657^{*} \\
(1.81) \\
\end{array}$ & $\begin{array}{l}-2.912 * * \\
(2.04)\end{array}$ \\
\hline R-Squared (adj) & 0.48 & 0.46 & 0.46 & 0.48 & 0.46 & 0.44 & 0.44 & 0.43 & 0.45 \\
\hline Observations & 76 & 76 & 76 & 76 & 76 & 76 & 76 & 76 & 76 \\
\hline
\end{tabular}


Table 5: Different Measures of TMI

\begin{tabular}{|c|c|c|c|c|c|}
\hline & & \multicolumn{2}{|c|}{ CIF ASSUMPTION } & \multicolumn{2}{|c|}{ MEASUREMENT ERROR } \\
\hline & (Baseline) & (BACI CIF) & (Constant 10\%) & $\begin{array}{l}\text { (w/o lowest } \\
\text { quartile) }\end{array}$ & $\begin{array}{l}\text { (w/o below } \\
\text { median) }\end{array}$ \\
\hline Variables & $(1)$ & $(2)$ & $(3)$ & $(4)$ & $(5)$ \\
\hline CID & $\begin{array}{l}-0.002 \\
(0.04)\end{array}$ & $\begin{array}{l}-0.046 \\
(0.76)\end{array}$ & $\begin{array}{l}-0.089 \\
(1.23)\end{array}$ & $\begin{array}{l}-0.005 \\
(0.10)\end{array}$ & $\begin{array}{l}0.001 \\
(0.02)\end{array}$ \\
\hline Real GDP Growth & $\begin{array}{l}-0.012^{*} \\
(1.80)\end{array}$ & $\begin{array}{l}-0.019 * * \\
(2.13)\end{array}$ & $\begin{array}{l}-0.012 \\
(1.19)\end{array}$ & $\begin{array}{l}-0.012^{*} \\
(1.80)\end{array}$ & $\begin{array}{l}-0.011^{*} \\
(1.68)\end{array}$ \\
\hline Inflation Diff. & $\begin{array}{l}0.014^{*} \\
(1.88)\end{array}$ & $\begin{array}{l}0.011 \\
(1.18)\end{array}$ & $\begin{array}{l}0.017 \\
(1.53)\end{array}$ & $\begin{array}{l}0.016^{* *} \\
(2.14)\end{array}$ & $\begin{array}{l}0.016 * * \\
(2.17)\end{array}$ \\
\hline Currency Misalignment & $\begin{array}{l}0.975^{* * * *} \\
(3.92)\end{array}$ & $\begin{array}{l}0.216 \\
(0.67)\end{array}$ & $\begin{array}{l}2.969 * * * \\
(7.71)\end{array}$ & $\begin{array}{l}0.831^{* * *} \\
(3.31)\end{array}$ & $\begin{array}{l}0.862 * * * \\
(3.46)\end{array}$ \\
\hline Gov. Debt & $\begin{array}{l}0.005 * \\
(1.95)\end{array}$ & $\begin{array}{l}0.007 * * \\
(2.12)\end{array}$ & $\begin{array}{l}-0.005 \\
(1.36)\end{array}$ & $\begin{array}{l}0.004^{*} \\
(1.68)\end{array}$ & $\begin{array}{l}0.003 \\
(1.34)\end{array}$ \\
\hline Exr. volatility & $\begin{array}{l}0.184 * * \\
(2.40)\end{array}$ & $\begin{array}{l}0.263 * * \\
(2.63)\end{array}$ & $\begin{array}{l}0.116 \\
(0.98)\end{array}$ & $\begin{array}{l}0.195 * * \\
(2.51)\end{array}$ & $\begin{array}{l}0.188 * * \\
(2.44)\end{array}$ \\
\hline Import Duties Ratio & $\begin{array}{l}-0.069 * * \\
(2.24)\end{array}$ & $\begin{array}{l}-0.109 * * * \\
(2.73)\end{array}$ & $\begin{array}{l}0.044 \\
(0.92)\end{array}$ & $\begin{array}{l}-0.082^{* * *} \\
(2.65)\end{array}$ & $\begin{array}{l}-0.081^{* *} \\
(2.63)\end{array}$ \\
\hline Constant & $\begin{array}{l}-0.350 \\
(1.16) \\
\end{array}$ & $\begin{array}{l}0.074 \\
(0.19) \\
\end{array}$ & $\begin{array}{l}-1.392^{* * *} \\
(3.00) \\
\end{array}$ & $\begin{array}{l}-0.247 \\
(0.81) \\
\end{array}$ & $\begin{array}{l}-0.211 \\
(0.70) \\
\end{array}$ \\
\hline $\begin{array}{l}\text { R-Squared (adj) } \\
\text { Observations }\end{array}$ & $\begin{array}{l}0.57 \\
92\end{array}$ & $\begin{array}{l}0.42 \\
92 \\
\end{array}$ & $\begin{array}{l}0.70 \\
92 \\
\end{array}$ & $\begin{array}{l}0.57 \\
92 \\
\end{array}$ & $\begin{array}{l}0.57 \\
92\end{array}$ \\
\hline
\end{tabular}

Notes: OLS estimates with t-statistics in parentheses. All specifications include quarterly dummies (not reported). *,

$* *$, $* * *$ indicate variables significant at $10 \%, 5 \%$, and $1 \%$ level respectively. 
Table 6: TMI - Estimation Method and Specification Issues

\begin{tabular}{|c|c|c|c|c|c|c|}
\hline & Baseline / OLS & SUR & Dynamic & $\begin{array}{l}\text { IV } \\
\text { (CID; Imp. Duties) }\end{array}$ & $\begin{array}{l}\text { IV } \\
\text { (Imp. Duties) }\end{array}$ & $\begin{array}{l}\text { EMU-membership / } \\
\text { Structural Break }\end{array}$ \\
\hline Variables & $(1)$ & $(2)$ & (3) & (6) & (7) & $(8)$ \\
\hline CID & $\begin{array}{l}-0.002 \\
(0.04)\end{array}$ & $\begin{array}{l}0.017 \\
(0.39)\end{array}$ & $\begin{array}{l}0.011 \\
(0.23)\end{array}$ & $\begin{array}{l}-0.014 \\
(0.31)\end{array}$ & $\begin{array}{l}-0.014 \\
(0.31)\end{array}$ & $\begin{array}{l}-0.003 \\
(0.06)\end{array}$ \\
\hline Real GDP Growth & $\begin{array}{l}-0.012^{*} \\
(1.80)\end{array}$ & $\begin{array}{l}-0.009 \\
(1.40)\end{array}$ & $\begin{array}{l}-0.011 \\
(1.64)\end{array}$ & $\begin{array}{l}-0.013^{*} \\
(1.96)\end{array}$ & $\begin{array}{l}-0.013^{*} \\
(1.96)\end{array}$ & $\begin{array}{l}-0.012 * \\
(1.71)\end{array}$ \\
\hline Inflation Diff. & $\begin{array}{l}0.014^{*} \\
(1.88)\end{array}$ & $\begin{array}{l}0.007 \\
(0.99)\end{array}$ & $\begin{array}{l}0.014^{*} \\
(1.95)\end{array}$ & $\begin{array}{l}0.015^{* *} \\
(2.08)\end{array}$ & $\begin{array}{l}0.015^{* *} \\
(2.08)\end{array}$ & $\begin{array}{l}0.014^{*} \\
(1.88)\end{array}$ \\
\hline Currency Misalignment & $\begin{array}{l}0.975^{* * *} \\
(3.92)\end{array}$ & $\begin{array}{l}1.087^{* * *} \\
(3.59)\end{array}$ & $\begin{array}{l}1.167 * * * \\
(4.08)\end{array}$ & $\begin{array}{l}0.900^{* * *} \\
(3.73)\end{array}$ & $\begin{array}{l}0.901^{* * *} \\
(3.74)\end{array}$ & $\begin{array}{l}1.008^{* * *} \\
(3.46)\end{array}$ \\
\hline Gov. Debt & $\begin{array}{l}0.005^{*} \\
(1.95)\end{array}$ & $\begin{array}{l}0.004 * * \\
(1.97)\end{array}$ & $\begin{array}{l}0.005^{* *} \\
(2.07)\end{array}$ & $\begin{array}{l}0.002 \\
(1.01)\end{array}$ & $\begin{array}{l}0.003 \\
(1.03)\end{array}$ & $\begin{array}{l}0.005^{*} \\
(1.91)\end{array}$ \\
\hline Exr. volatility & $\begin{array}{l}0.184 * * \\
(2.40)\end{array}$ & $\begin{array}{l}0.265 * * * \\
(3.47)\end{array}$ & $\begin{array}{l}0.196 * * \\
(2.48)\end{array}$ & $\begin{array}{l}0.231^{* * *} \\
(3.03)\end{array}$ & $\begin{array}{l}0.230 * * * \\
(3.01)\end{array}$ & $\begin{array}{l}0.182 * * \\
(2.34)\end{array}$ \\
\hline Import Duties Ratio & $\begin{array}{l}-0.069 * * \\
(2.24)\end{array}$ & $\begin{array}{l}-0.091^{* * * *} \\
(3.34)\end{array}$ & $\begin{array}{l}-0.073 * * \\
(2.33)\end{array}$ & $\begin{array}{l}-0.131^{* * *} \\
(3.37)\end{array}$ & $\begin{array}{l}-0.129 * * * \\
(3.33)\end{array}$ & $\begin{array}{l}-0.068 * * \\
(2.20)\end{array}$ \\
\hline Lagged TMI & & & $\begin{array}{l}-0.064 \\
(0.59)\end{array}$ & & & \\
\hline EMU-membership & & & & & & $\begin{array}{l}0.009 \\
(0.22)\end{array}$ \\
\hline Constant & $\begin{array}{l}-0.350 \\
(1.16)\end{array}$ & $\begin{array}{l}-0.232 \\
(0.88)\end{array}$ & $\begin{array}{l}-0.388 \\
(1.29)\end{array}$ & $\begin{array}{l}0.171 \\
(0.48)\end{array}$ & $\begin{array}{l}0.158 \\
(0.44)\end{array}$ & $\begin{array}{l}-0.357 \\
(1.17)\end{array}$ \\
\hline R-Squared (adj) & 0.57 & 0.71 & 0.57 & 0.54 & 0.54 & 0.56 \\
\hline Observations & 92 & $76 / 76$ & 91 & 92 & 92 & 92 \\
\hline
\end{tabular}

Notes: OLS estimates with t-statistics in parentheses. All specifications include quarterly dummies (not reported). *, **, *** indicate variables significant at $10 \%, 5 \%$, and $1 \%$ level respectively. 
Table 7: T2 - Estimation Method and Specification Issues

\begin{tabular}{|c|c|c|c|c|c|c|}
\hline & Baseline / OLS & SUR & Dynamic & $\begin{array}{l}\text { IV } \\
\text { (CID; Spread) }\end{array}$ & IV (Spread) & $\begin{array}{l}\text { EA Crisis / } \\
\text { Structural Break }\end{array}$ \\
\hline Variables & (1) & (2) & (3) & (6) & (7) & $(8)$ \\
\hline CID & 0.150 & 0.097 & 0.117 & -0.384 & 0.518 & 0.155 \\
\hline \multirow[t]{2}{*}{ Currency Misalignment } & 1.186 & 1.913 & 1.120 & 1.055 & 1.388 & 1.156 \\
\hline & $(0.34)$ & $(0.60)$ & $(0.32)$ & $(0.31)$ & $(0.41)$ & $(0.33)$ \\
\hline \multirow[t]{2}{*}{ Gov. Debt } & $0.035 *$ & $0.034 *$ & $0.035 *$ & $0.036 *$ & $0.038 *$ & $0.035 *$ \\
\hline & $(1.72)$ & $(1.85)$ & $(1.69)$ & $(1.84)$ & $(1.93)$ & $(1.71)$ \\
\hline \multirow[t]{2}{*}{ D(EA Spread) } & $-1.136^{* * *}$ & $-1.098 * * *$ & $-1.158 * * *$ & $-1.497 * * *$ & $-1.723 * * *$ & $-1.135^{* * *}$ \\
\hline & $(5.00)$ & $(2.31)$ & $(4.83)$ & (3.23) & $(5.02)$ & $(4.96)$ \\
\hline \multirow[t]{2}{*}{ Collateral Standards } & $-0.641 * *$ & $-0.670 * *$ & $-0.641 *$ & -0.519 & $-0.646 * *$ & $-0.642 * *$ \\
\hline & $(2.01)$ & $(2.31)$ & $(1.98)$ & $(1.37)$ & $(2.09)$ & $(2.00)$ \\
\hline \multirow[t]{2}{*}{ Collateral (Idiosyncratic) } & $-3.946 * * *$ & $-3.647 * * *$ & $-3.901 * * *$ & $-3.402 * * *$ & $-3.690 * * *$ & $-3.945 * * *$ \\
\hline & (3.65) & $(3.71)$ & (3.53) & (2.89) & (3.49) & $(3.62)$ \\
\hline \multirow[t]{2}{*}{ EU EPU (Expert) } & $-0.008 * * *$ & $-0.007 * *$ & $-0.009 * *$ & $-0.009 * *$ & $-0.010 * * *$ & $-0.008 * *$ \\
\hline & $(2.66)$ & $(2.53)$ & $(2.62)$ & $(2.55)$ & $(3.15)$ & $(2.64)$ \\
\hline Lagged T2 & & & $(0.34)$ & & & \\
\hline \multirow[t]{2}{*}{ EA Crisis } & & & & & & -0.109 \\
\hline & & & & & & $(0.10)$ \\
\hline \multirow[t]{2}{*}{ Constant } & -1.675 & -1.793 & -1.612 & -1.518 & -1.836 & -1.575 \\
\hline & $(1.14)$ & $(1.32)$ & $(1.07)$ & $(1.00)$ & $(1.29)$ & $(0.89)$ \\
\hline R-Squared (adj) & 0.48 & 0.55 & 0.47 & 0.43 & 0.43 & 0.47 \\
\hline Observations & 76 & $76 / 76$ & 75 & 76 & 76 & 76 \\
\hline
\end{tabular}

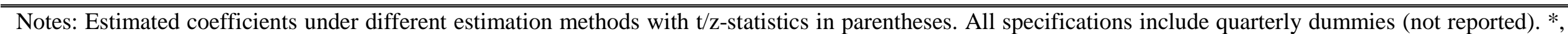

$* *$, *** indicate variables significant at $10 \%, 5 \%$, and $1 \%$ level respectively. 